\title{
14. CRETACEOUS PLANKTONIC FORAMINIFERS FROM DSDP LEG 40, SOUTHEASTERN ATLANTIC OCEAN
}

\author{
Michèle Caron, University of Fribourg, Switzerland
}

\begin{abstract}
Cretaceous sections were drilled at Site 361 in the Cape Basin, Site 363 on Walvis Ridge, and Site 364 in the Angola Basin, during Leg 40: Except for two samples (14-2, 137-141 cm and 27-2, $35 \mathrm{~cm})$, the Cretaceous of Site 361 is barren of planktonic foraminifers. Sites 363 (Cores 18-40) and 364 (Cores 11-46) penetrated Cretaceous sediments ranging, with some interruptions, from Aptian to Maestrichtian. The lowermost sediments of Sites 363 and 364 containing planktonic foraminifers are upper Aptian. Sedimentation was apparently continuous throughout the Albian with a rich fauna of predominantly non-keeled forms. The environment must have been cool during this period. The planktonic foraminifers on Walvis Ridge and in the Angola Basin show certain parallels. Cores 25-22 of the Walvis Ridge Site 363 , immediately above the Aptian-Albian Cores $41-26$, are void of planktonic foraminifers, probably due to an elevated carbonate compensation depth. On calcareous nannoplankton evidence this interval falls within the upper Turonian to Campanian, indicating that Cenomanian and lower Turonian are absent at this site. The next higher core at Site 363, Core 21, with a rich tethyan fauna, is lower Maestrichtian. Similarly, Cores 25 and 24 of the Angola Basin Site 364, above the Aptian-Albian Cores 41-26, contain but very few planktonic foraminifers. On calcareous nannoplankton these two cores are dated as upper Albian. Thus Cenomanian and lower Turonian seem to be absent or much reduced in the Angola Basin site. That Cenomanian sediments containing planktonic foraminifers must have been deposited at least in parts of the Angola Basin as indicated by a sample recovered in Site 365 which contains a single reworked specimen of Rotalipora appenninica, together with other Cenomanian species. At Site 364, Core 23 with Turonian, and Cores 22 and 21 with Coniacian planktonic foraminifers prove that at least parts of these two stages are present in the Angola Basin site. At Site 364, Cores 20 to 15 are placed in the Santonian to Campanian and 14 and 13 in the lower Maestrichtian. Dissolution is strong in parts of Site 364 , Cores 23 to 13 ; in Cores 12 and 11 planktonic foraminifers are totally absent.

In contrast, the Maestrichtian planktonic foraminifers at Walvis Ridge Site 363 , Cores 21 to 18 are well preserved. With no distinct Cenomanian and only poor Turonian planktonic foraminifers, only the Coniacian and younger faunas are seen to have a high proportion of tethyan elements. This is the first indication that an influx of warmer waters reached the Angola Basin and the Walvis Ridge area, apparently as a consequence of the opening of the Atlantic to the north.
\end{abstract}

\section{INTRODUCTION}

Sites 363 and 364 on Leg 40 were chosen to gain insight on the role of the Walvis Ridge during the opening of the South Atlantic. At Site 363 about 400 meters of Cretaceous sediments were drilled and recovered in Cores 18-40. Basement was not reached in this site but the volcanic substratum is probably only some tens of meters below the last core taken (see Figure 1).
Cretaceous sediments of the Angola Basin Site 364 are nearly 700 meters thick and are contained in Cores 11-46. The hole reached 1086 meters subbottom, terminating at just about acoustic basement, considered here to be salt (see Chapter 4).

Certain difficulties were encountered in the identification of species and determination of biozones; sorting is frequent throughout all 12 cores, as is some contamination and possible reworking. In addition, cold Antarctic waters (dominant during Albian on the 


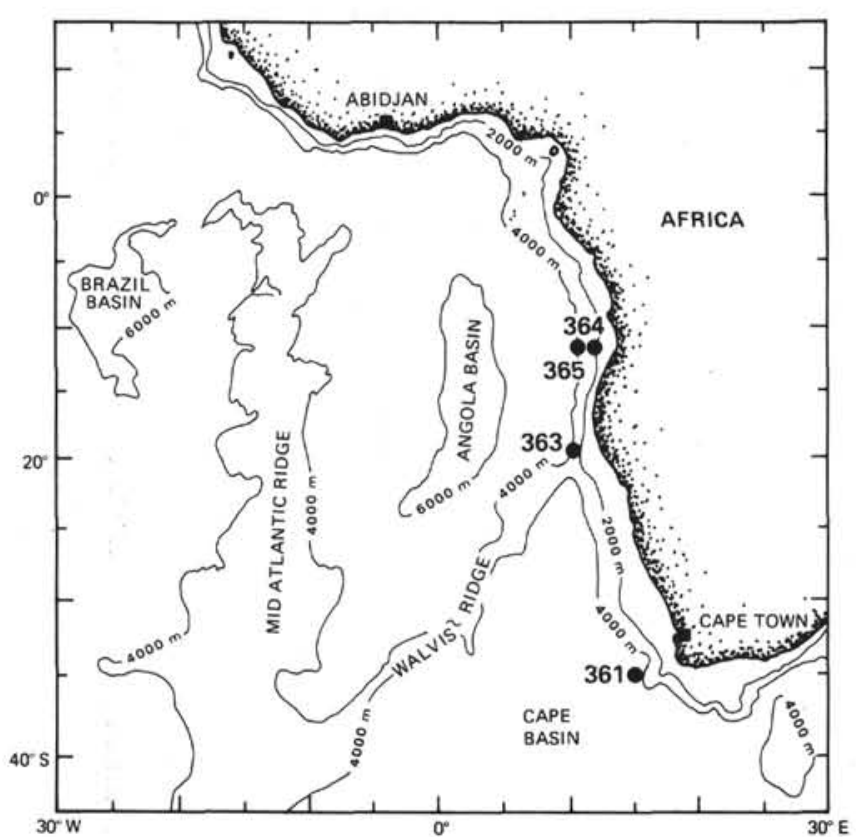

Figure 1. Location of Leg 40 Sites 361, 363, 364, and 365 .

Walvis Ridge) or hypersaline conditions in a restricted environment (Angola Basin from Aptian to the end of Albian) led to variations in the aspect of the planktonic foraminifer populations. Not only do forms of Hedbergella-type proliferate, but there is a general deviation towards this type from the genera Globigerinelloides and Ticinella (few or no supplementary apertures), as well as to the general absence of keeled forms in the population. There is also a diminution in the number of chambers of the species which normally have more than six in the last whorl (Biticinella $\mathrm{cf}$. breggiensis $\rightarrow$ Globigerinelloides texomaensis, Ticinella cf. roberti, Hedbergella cf. trochoidea, Globigerinelloides $\mathrm{cf}$. ferreolensis).

The significant local species are indicated in the text, together with the biozones defined in the tethyan realm with which the sections are correlated (Figure 2).

\section{PLANKTONIC FORAMINIFER ASSEMBLAGES FROM SITES 363, 364, AND 365}

\section{Site 363-Walvis Ridge}

Upper Aptian-Basal Albian, Globigerinelloides algeriana to Ticinella bejaouensis Zone (Cores 39-31, CC)

Core 40 , the lowermost taken, does not contain planktonic foraminifers, those in Cores $39-35$ are as a rule rare, with most species belonging to the genus Hedbergella.

The interval cannot be clearly delimited mainly for difficulties with generic and specific determinations. Identifications are good for Hedbergella planispira, abundant in Core 36, Section 1, and Hedbergella infracretacea in Core 33, Section 4. Also occurring are small forms determined to be Hedbergella cf. washitensis, Favusella sp. indet., and several specimens of Globigerinelloides maridalensis which frequently possess low trochospiral coiling similar to the Hedbergellids occurring in colder waters.

Hedbergella infracretacea gargasiana Moullade (Plate 1, Figures 7-9) a distinctive subspecies and a good stratigraphic marker, occurs in these cores. It is limited to the upper Aptian in the Vocontian trough of France. However, the presence of Clavihedbergella simplicissima (=amabilis) suggests that this interval could well be younger.

\section{Albian, Ticinella primula to Rotalipora ticinensis Zone (Cores 31-26, Section 1)}

The Albian is characterized by the first appearance of Ticinella and by the continuous presence of Hedbergella infracretacea, $H$. planispira, and $H$. delrioensis.

The Ticinella primula Zone (Core 31, Section 1, Core 30 , Section 1) bridges the lower/middle Albian boundary. Because of its hedbergelloid trend, Ticinella primula is not very characteristic in these cores. Few Globigerinelloides maridalensis and $G$. caseyi specimens are present.

The markers of the Biticinella breggiensis to Rotalipora ticinensis zones (Core 29, CC-Core 26, Section 1) are missing in the samples studied, but the presence of few Ticinella roberti, some $T$. primula, Hedbergella trochoidea, $H$. costellata, and rare Ticinella praeticinensis, indicate a middle to upper Albian age for this interval.

In Core 29, a group of planktonic foraminifers with strong ornamentation (pustulae and costulae) undamaged by dissolution, indicates a more neritic episode. This characteristic fauna is more frequent in Cores 30 and 31 of the Angola Basin.

The closest description of such forms are found in Saint-Marc (1973) who describes Hedbergella costellata from a middle Cenomanian neritic environment of Lebanon, and in Fondecave (1975) with Hedbergella aubertae from the Pyrénées.

The locally characteristic species of this interval are Ticinella praeticinensis, associated with $T$. roberti, and $T$. primula continuing from the previous zone. Hedbergella "with costellae" is here considered a facies indicator but not a good time marker. It may be used for short distance correlation such as between the Walvis Ridge and the Angola Basin (see also discussion on the Albian of Site 364).

\section{Cenomanian-Campanian (Cores 22-25)}

No planktonic foraminifers are present in these cores, but benthic foraminifers and calcareous nannoplankton are abundant. The reason for their absence is either dissolution or adverse environmental conditions

\section{Maestrichtian, Globotruncana havanensis to Globotruncana mayaroensis Zone (Cores 21-18)}

The approximately 60 meters of sediments represented by Cores 22-25 without planktonic foraminifers are overlain by a foraminifer marl rich in well-preserved Globotruncana species of Tethyan aspect. 


\begin{tabular}{|c|c|c|c|c|c|c|}
\hline \multicolumn{2}{|l|}{ AGE } & \multicolumn{2}{|c|}{ STAGE } & PLANKTONIC FORAMINIFERAL ZONES & SITE 363 & SITE 364 \\
\hline \multirow{30}{*}{ CRETACEOUS } & \multirow{18}{*}{$U$} & \multirow{3}{*}{\multicolumn{2}{|c|}{ Maastrichtian }} & Globotruncana mayaroens is & $18-19 / 2$ & \\
\hline & & & & Globotruncana gansseri & $19 / 4-20$ & \\
\hline & & & & Globotruncana havanens is & 21 & $13-14$ \\
\hline & & \multirow{3}{*}{\multicolumn{2}{|c|}{ Campanian }} & Globotruncana cal carata & \multirow[t]{16}{*}{22} & \multirow[t]{4}{*}{15} \\
\hline & & & & Globotruncana ventricosa & & \\
\hline & & & & Globotruncana fornicata & & \\
\hline & & \multirow{2}{*}{\multicolumn{2}{|c|}{ Santonian }} & Globotruncana concavata carinata & & \\
\hline & & & & Globotruncana concavata & & 20 \\
\hline & & \multirow{2}{*}{\multicolumn{2}{|c|}{ Coniacian }} & Globotruncana primitiva & & $21-22$ \\
\hline & & & & & & \\
\hline & & \multirow{3}{*}{\multicolumn{2}{|c|}{ Turonian }} & Globotruncana sigali & & 23 \\
\hline & & & & Globotruncana helvetica & & \multirow{8}{*}{24} \\
\hline & & & & Hedbergella portsdownens is & & \\
\hline & & \multirow{5}{*}{\multicolumn{2}{|c|}{ Cenomanian }} & Rotalipora cushmani & & \\
\hline & & & & Rotalipora reicheli & & \\
\hline & & & & Rotalipora greenhornensis & & \\
\hline & & & & Rotalipora gandolfii & & \\
\hline & & & & Rotalipora brotzeni & & \\
\hline & \multirow{12}{*}{ L } & \multirow{5}{*}{ Albian } & \multirow{2}{*}{ Vraconian } & Rotalipora apenninica & & \\
\hline & & & & Planomalina buxtorfi & 25 & 25 \\
\hline & & & U & Rotalipora ticinens is & 26 & \multirow{2}{*}{$26-31 / 1$} \\
\hline & & & $M$ & Biticinella breggiensis & 29 & \\
\hline & & & $\mathrm{L}$ & Ticinella primula & $30-31 / 1$ & \multirow{2}{*}{$\begin{array}{l}31 \mathrm{cc} \\
34\end{array}$} \\
\hline & & \multirow{5}{*}{\multicolumn{2}{|c|}{ Clansayesian }} & Ticinella bejaovens is & \multirow[t]{3}{*}{$31 \mathrm{cc}$} & \\
\hline & & & & Hedbergella trochoidea & & $35-37$ \\
\hline & & & & Hedbergella gorbachikae & & \\
\hline & & & & Globigerinelloides algeriana & 39 & $38-41$ \\
\hline & & & & Schackoina cabri & & \\
\hline & & L & Bedoulian & Globigerinelloides blowi & & \\
\hline & & Barremi & & Hedbergella sigali & & \\
\hline
\end{tabular}

Figure 2. Planktonic foraminifer zonal scheme used in this paper, synthesised after van Hinte (1976), Longoria (1974), Porthault (1974), and Moullade (1966).

Three zones are distinguished from bottom to top:

1) Globotruncana havanensis Zone (Core 21). Here the characteristic Globotruncana leupoldi and $G$. fornicata concur with the zonal marker.

2) Globotruncana gansseri Zone (Cores 20-19, Section 4). Probably as a result of a decrease in CCD, species not present earlier occur, such as Globotruncana elevata, $G$. stuartiformis, and $G$. subspinosa. The presence of $G$. gansseri, $G$. stuarti, $G$. aegyptiaca, $G$. intermedia, and $G$. contusa restricts this zone to the middle Maestrichtian.

3) Globotruncana mayaroensis Zone (Cores 19, Section 2-18) This marker associated with the Rugoglobigerina group and Racemiguembelina fructicosa dates the interval as upper Maestrichtian.

\section{Site 364-Angola Basin}

The planktonic foraminifers Ticinella bejaouensis (Plate 2, Figures 9,10), contained in the dolomitic and black sapropelic shales of the lowermost cores are preserved as carbonate casts showing fine prints of pores and apertures. From Core 41 to Core 34, Section 2 , the solution of calcareous tests is strong, but the calcareous microfauna remains rich because of the exceptional preservation of the casts. The dominant forms are of the Hedbergella-type. Not only are individuals abundant, but also species show normal diversity. The solution of the original calcitic test may have begun only after empty shells had been filled with carbonate, during or after sinking to the bottom. It may not be necessary to envisage a great depth of 
deposition, near or below the lysocline because, according to Herb and Scheibnerova (manuscript), partial or complete solution of calcitic tests can be attributed to dissolution under reducing conditions in the sediment shortly after deposition. This may well be the case for the Angola Basin at this time, with its stagnant, confined, euxinic conditions.

Upper Aptian, Globigerinelloides algeriana to

Hedbergella trochoidea Zone (Cores 41-35/1)

The genus Hedbergella represents the majority of species among which some index species allow for definition of two zonal intervals:

1) Globigerinelloides algeriana Zone (Cores 41-38): Although the Tethyan index species is missing in the samples studied, the following faunal association is sufficient to characterize the zone: few Globigerinelloides blowi, one specimen of G. barri, some G. maridalensis with hedbergelloid tendency (as in the upper Aptian of Site 363), and first appearance of Hedbergella gorbachikae.

Hedbergella infracretacea gargasiana occurs together with numerous $H$. planispira, $H$. infracretacea and $H$. delrioensis, as in the deepest cores of Site 363. This association is dated upper Gargasian in the Tethyan area.

2) Hedbergella gorbachikae to Hedbergella trochoidea Zone (Cores 37-35). This interval corresponds to Longoria's Hedbergella gorbachikae Zone based on the association Hedbergella maslakovae (numerous in places), $H$. labocaensis, and the last occurrence of $H$. gorbachikae. Still predominant are $H$. planispira, $H$. delrioensis, and $H$. infracretacea.

\section{Albian, Ticinella bejaouensis to \\ Rotalipora ticinensis Zone (Cores 34-26)}

At the base of Core 34, tests show strong dissolution and specimens are preserved as casts. Upwards, dissolution abruptly diminishes, allowing for the preservation of a high genus and species diversity. The Ticinella-group controls this stage which is subdivided as follows:

1) Ticinella bejaouensis-Ticinella primula zones, lower to middle Albian (Cores 34-31, CC). Ticinella bejaouensis, $T$. primula, and $T$. madecassiana complement the Hedbergella population of the previous zone (the sporadic occurrence of Hedbergella gorbachikae, H. labocaensis, and H. maslakovae may be due to contamination or reworking from an unlithified bottom). Globigerinelloides bentonensis and $G$. texomaensis make their first appearance within this interval.

2) Biticinella breggiensis-Rotalipora ticinensis zones, middle to upper Albian (Sections 31-1 to 26-3). As on Walvis Ridge, index species are missing here, but the abundance of Ticinella, with $T$. praeticinensis date the interval. They occur together with Globigerinelloides bentonensis, $G$. texomaensis, and $G$. caseyi. The presence of Clavihedbergella (simplicissima and simplex), and of Schackoina (cenomana, bicornis, moliniensis, and pentagonalis) is unusual. These have never been recorded at this early level. Further, a considerable number of Whiteinella (bornholmensis and baltica) are present in this interval, but these were described by Douglas and Rankin (1969) from the upper Turonian-Coniacian of the Baltic Sea, and therefore possibly indicate contamination from above; they may in fact have a range extending below the Turonian. Their occurrence may also reflect a more neritic type of environment. They occur locally (Cores 31, Section 1, 30, and 38, CC) together with a rich population of Hedbergella "à costellae" similar to those described by Saint-Marc (1973) in a Cenomanian neritic facies of Lebanon. In Figure 4, Hedbergella costellata Saint-Marc is representative of this population, and is characterized by heavy ornamentation consisting of radially, spirally, or circularly arranged pustulae and costulae: cf. Hedbergella costellata, Plate 4, Figures 3-9; Ticinella sp., Plate 5, Figure 7; Ticinella $\mathrm{cf}$. roberti, Plate 6, Figures 1-4; Ticinella praeticinensis, Plate 7, Figures 1, 2; and even Praeglobotruncana delrioensis, Plate 7, Figures 3, 4.

Cores 25-24: Planktonic foraminifers are very strongly dissolved. The few specimens preserved (see Figure 5) do not allow for a stratigraphic determination. Based on calcareous nannoplankton the interval still falls in the upper Albian. Cenomanian thus appears to be absent at Site 364 .

\section{Turonian}

The fauna is poor and strongly to moderately dissolved. Only some Hedbergella delrioensis, $H$. infracretacea, and $H$. portsdownensis remain, together with frequent $H$. crassa which seems to be more resistant to solution than the other planktonic foraminifers of this level (Figure 5).

\section{Upper Coniacian, Globotruncana primitiva Zone}

(Cores 22-21)

The fauna again becomes very rich with numerous genera and species dominated by Hedbergella. Whiteinella archaeocretacea, $W$. baltica, and $W$. bornholmensis occur in their known stratigraphic position as described by Douglas and Rankin (1969). Clavihedbergella also occurs, but the most representative group for environment and biozonation is that of Globotruncana. The Globotruncana primitiva Zone is characterized by the typical Tethyan association, Globotruncana sigali, $G$. imbricata, $G$. sinuosa, $G$. primitiva, $G$. renzi, $G$. coronata, and $G$. pseudolinneiana. All are large specimens with keels and normally developed apertures.

At this time, warm water flowing southward began its strong and lasting influence on the Angola Basin.

\section{Santonian to Campanian (Cores 20-15)}

The basin appears to have sunk below the carbonate compensation depth at this time, as evidenced by generally strong dissolution of planktonic foraminifer tests; the only resistant forms are a few Globotruncana including G. fornicata and Hedbergella crassa.

\section{Maestrichtian (Cores 14-13)}

The microfauna is partially dissolved, and therefore impoverished, but members of the Globotruncana 


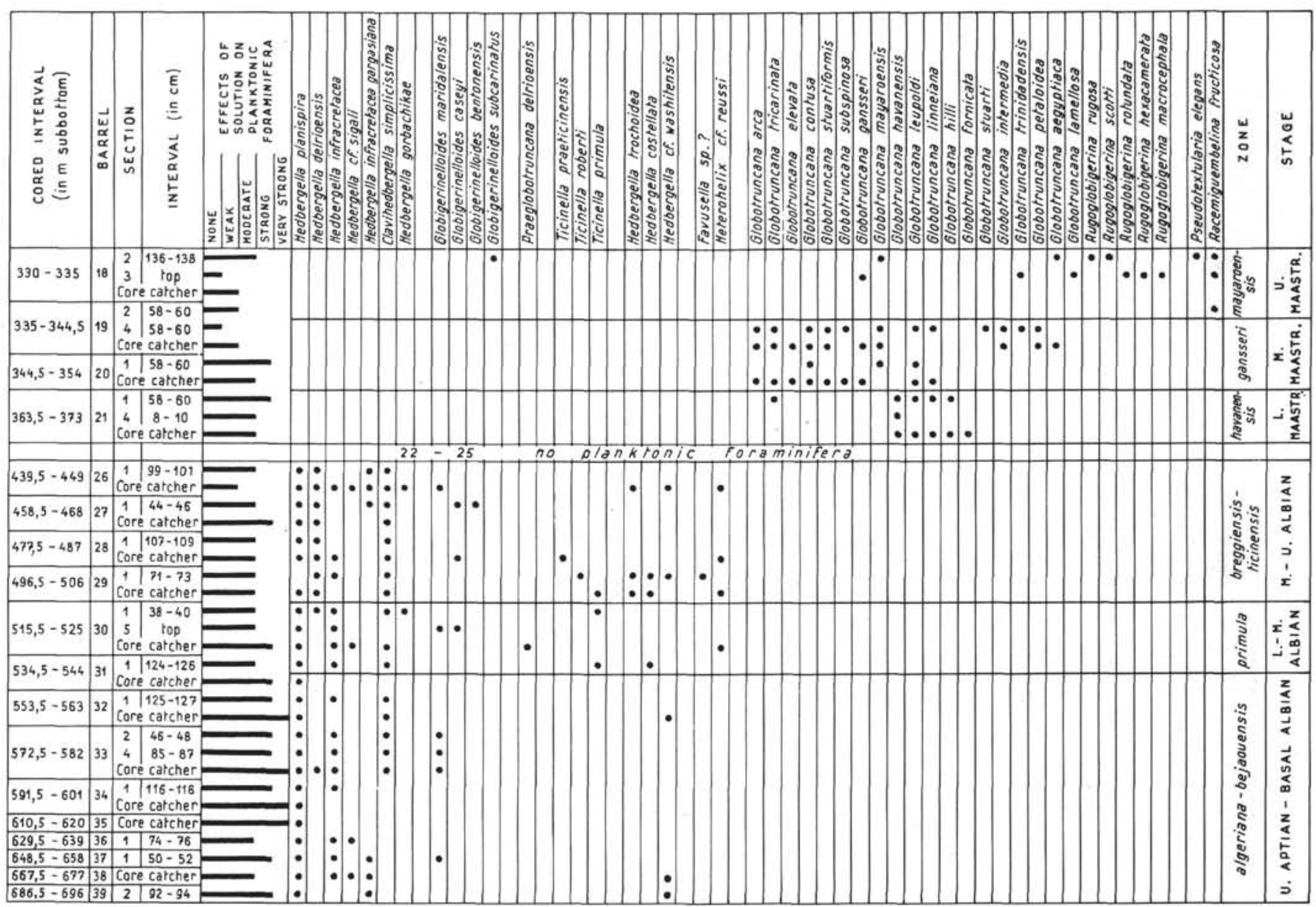

Figure 3. Distribution of Cretaceous planktonic foraminifers at Site 363, Cores 18-39.

havanensis Zone (lower Maestrichtian) occurs here including Globotruncana leupoldi, G. stuartiformis, G. elevata, and $G$. havanensis which are typical Tethyan species.

\section{Site 365-Angola Basin}

This site, situated some 20 miles northwest of Site 364 , seawards of the marginal escarpment, was chosen for the possibility of being a complementary section to Site 364 in that it was expected to bypass the upper part of that site and reach acoustic basement. These objectives were not met; the hole terminated in the Oligocene.

Of some interest at this site is the occurrence of reworked Cretaceous foraminifers and calcareous nannoplankton in the Tertiary sediments. They are present in particular from the lower part of Cores 1 to 3 . The richest planktonic foraminifer fauna occurs in Core 3, CC with Hedbergella delrioensis, $H$. portsdownensis, and $H$. costellata; Clavihedbergella simplicissima; Praeglobotruncana delrioensis, $P$. stephani, and $P$. stephani gibba; Rotalipora praebalernaensis and $R$. appenninica (one well-preserved specimen).

Such an association, in particular Rotalipora appenninica, was not encountered at Site 363 or the nearby Site 364. It is evidence that Cenomanian sediments containing planktonic foraminifers were deposited in part of the Angola Basin, some of which later became eroded and redeposited such as in the younger sediments of Site 365 .

\section{COMPARISON BETWEEN THE WALVIS RIDGE AND THE ANGOLA BASIN (SITES 363 AND 364)}

\section{Aptian}

The Hedbergella group is predominant; sedimentation seems synchronous in the two localities. A difference exists in the preservation of planktonic tests; it is better in the Angola Basin where specimens have been preserved in the form of casts.
Albian
The first Ticinella are atypical forms; they are less than medium-sized and show only one or two sutural supplementary apertures. On the ridge, the fauna is not as rich and specimens are of smaller size than in the basin (sorting by currents?).
Hedbergella costellata are rarer and Whiteinella did not occur at this time on the Walvis Ridge.
The presence of some Aptian species, such as Hedbergella infracretacea gargasiana, H. gorbachikae, 


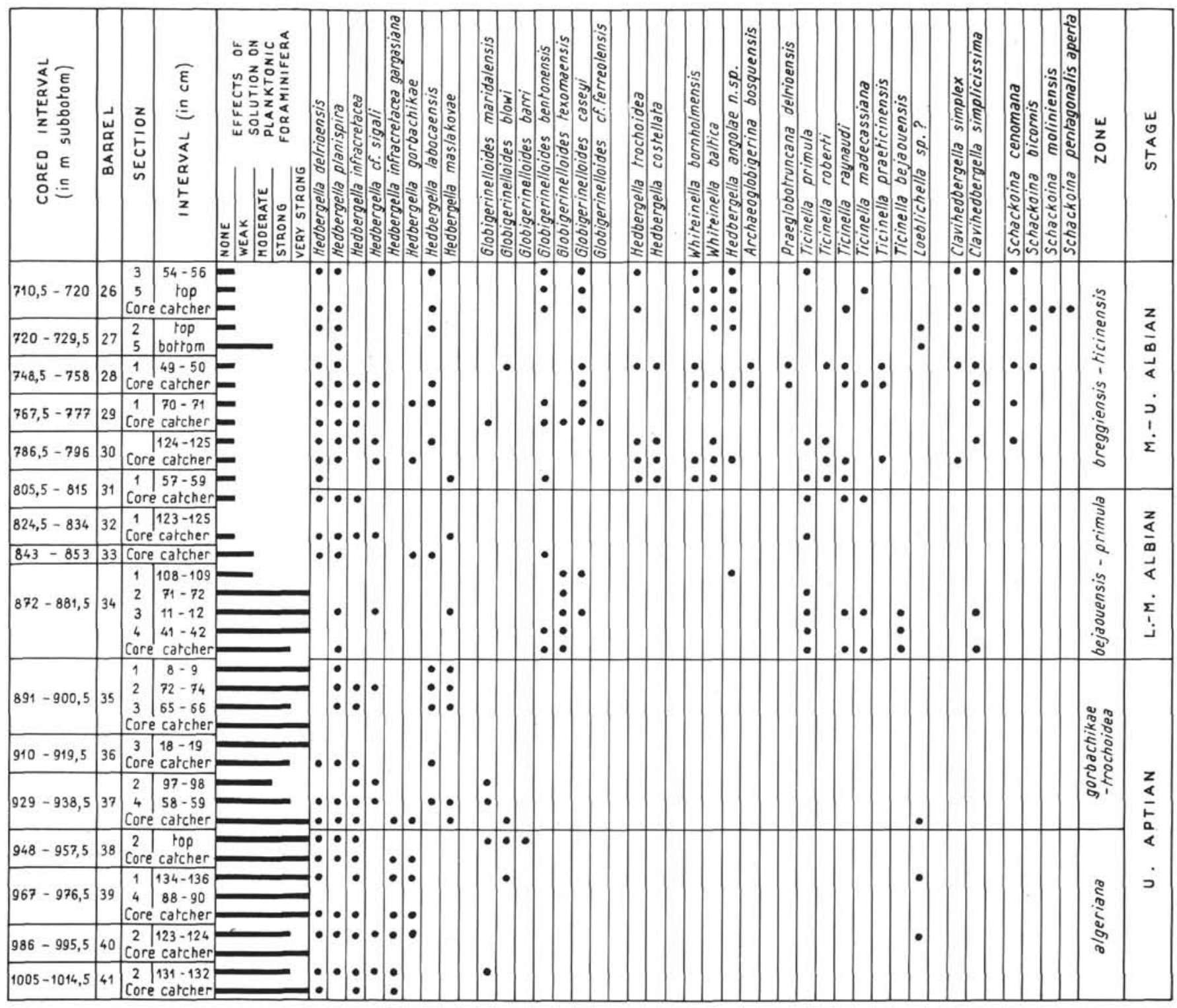

Figure 4. Distribution of Lower Cretaceous planktonic foraminifers at Site 364, Cores 26-41.

$H$. labocaensis, and $H$. maslakovae, throughout this stage points to possible reworking. I conclude that a cool environment prevailed during Albian time; the sorting is evidence that Walvis Ridge was swept by currents whereas the Angola Basin was confined since the upper Aptian. At about the middle Albian, conditions changed in the Angola Basin; tests no longer were dissolved, and the microfauna rapidly grew richer in shallower, possibly neritic forms (Clavihedbergella, Schackoina, Hedbergella "à costulae").

\section{Cenomanian}

Very little is known about this stage from planktonic foraminifers. Only at Site 365, a typical but reworked association occurs proving the presence of Cenomanian in the Angola Basin. The occurrence here of a single specimen of Rotalipora appenninica, of normal size and with a well-developed keel, is the first indicator of communication with warmer Tethyan waters.

\section{Turonian}

There is no planktonic foraminifer evidence for Turonian on Walvis Ridge. Only the planktonic foraminifers of Core 23 in Site 364, strongly affected by dissolution, point to an apparently reduced presence of Turonian in the Angola Basin.

\section{Coniacian}

On Walvis Ridge all tests are dissolved whereas in the Angola Basin (Core 22) a well-preserved microfauna reappears. It is rich in cool water species (Whiteinella) but is also invaded by warm water species that represent the complete association characteristic for the Globotruncana primitiva Zone of the Tethys.

\section{Santonian-Campanian}

No planktonic foraminifers of this age are preserved on the Walvis Ridge (that is from Cores 25 to 22, about 


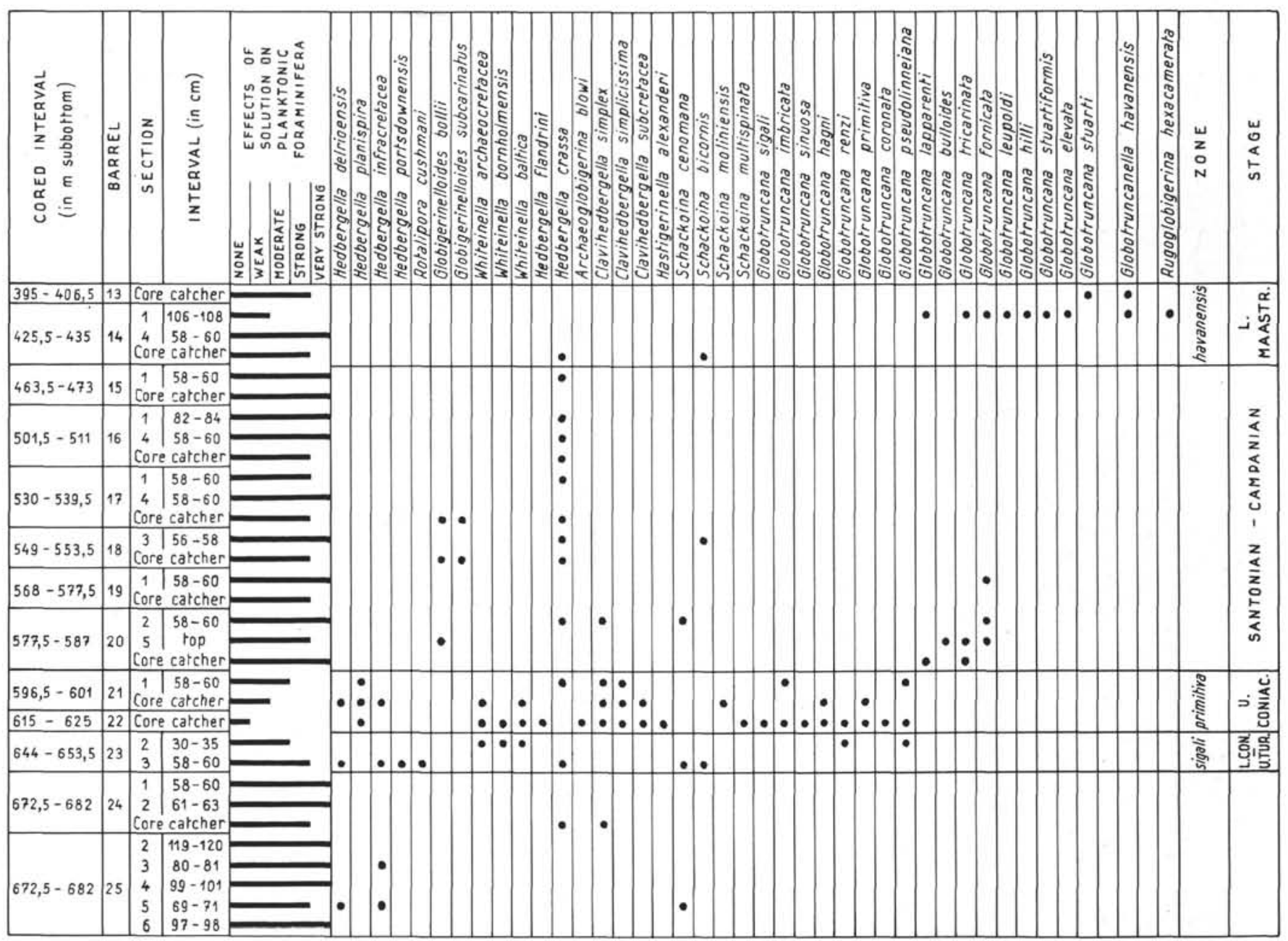

Figure 5. Distribution of Upper Cretaceous planktonic foraminifers at Site 364, Cores 13-25.

$65 \mathrm{~m}$ of sediment). In the Angola Basin dissolution has been so strong that only Hedbergella crassa and some Globotruncana fornicata specimens occur, showing that during this interval at least certain parts of the ridge and basin were at a depth near or below the lysocline, and were probably in communication with the Tethys.

\section{Maestrichtian}

Cores 21 to 18 of Walvis Ridge Site 363 represent a lower, middle, and upper Maestrichtian sequence with rich and well preserved planktonic foraminifers. They embrace the Globotruncana havanensis Zone (Core 21), the Globotruncana gansseri Zone (Cores 20-19, Section 4 ) and the Globotruncana mayaroensis Zone (Cores 19, Section 2-18). Tropical tethyan species are abundant.

During the same stage, planktonic foraminifers are not as well preserved at Site 364, but are nonetheless sufficiently numerous to define basal Maestrichtian in Cores 14 and 13, CC. Cores 12 and 11 , considered to be higher Maestrichtian on calcareous nannoplankton, are void of planktonic foraminifers, though benthic forms are present.

\section{REMARKS ON THE SYSTEMATICS OF SOME CRETACEOUS PLANKTONIC FORAMINIFERAL SPECIES}

The study of the Cretaceous planktonic foraminifers of Leg 40 is of interest mainly because of the unusual diversity of the Lower Cretaceous assemblages (high variety of Hedbergella, Globigerinelloides, and other non-keeled genera) indicating a cool paleoenvironment. From the Cenomanian onwards, tropical species began their southward migration, gradually increasing the tethyan species ratio in the South Atlantic. As those are the best described and illustrated species in micropaleontological literature, systematic remarks and SEM photographs are here restricted to the less known planktonic foraminifers of the upper Aptian and Albian.

The illustrated specimens are deposited at the Museum of Natural History, Basel, under the numbers C 33.768 to C 33.828 .

Genus GLOBIGERINELLOIDES Cushman and Ten Dam, 1948

Globigerinelloides? maridalensis (Bolli, 1959) (Plate 1, Figures 3, 4)

The species is fairly frequent during upper Aptian, but often shows a trend to a Hedbergella-type low trochospiral coiling. Upper Aptian, Sites 363 and 364 .

Globigerinelloides barri (Bolli, Loeblich, and Tappan, 1957)

Some specimens are not very typical (6-7 chambers in the last whorl instead of 8-9). Upper Aptian, Globigerinelloides algeriana Zone, Site 364. 
Globigerinelloides blowi (Bolli, 1959)

(Plate 6, Figures 11, 12)

Few specimens only occur which are similar to the type. Upper Aptian, Site 364 .

\section{Globigerinelloides texamaensis Michael, 1972} (Plate 2, Figures 7, 8)

This species is similar to Globigerinelloides bentonensis, but differs by having fewer chambers in the last whorl $(5-6)$. The ultimate chamber is very large, on both sides protruding towards the umbilicus. Lower to Middle Albian, Ticinella primula Zone to Biticinella breggiensis Zone, Site 364.

Globigerinelloides bentonensis (Morrow, 1934)

$$
\text { (Plate 2, Figures 5, 6) }
$$

Specimens usually have fewer chambers in the last whorl compared with the holotype. Lower to Upper Albian, Site 364.

Globigerinelloides caseyi (Bolli, Loeblich, and Tappan, 1957)

(Plate 3, Figure 8: Plate 6, Figures 8-10)

Typical forms occur in the two sites during Albian.

Genus SCHACKOINA Thalmann, 1932

Schackoina bicornis Reichel, 1948

Schackoina cenomana (Schacko, 1896)

(Plate 8, Figures 8, 9)

Schackoina moliniensis Reichel, 1948

(Plate 8, Figures 10, 11)

Schackoina pentagonalis aperta Reichel, 1948

(Plate 8, Figure 7)

These species occur in typical form, size, and ornamentation, but in an older level than so far known. They represent the middle and upper Albian,Biticinella breggiensis Zone to Rotalipora ticinensis Zone, Site 364.

They are again sporadically present throughout the Turonian to Maestrichtian.

\section{Genus HEDBERGELLA Bronnimann and Brown, 1958}

Hedbergella delrioensis (Carsey, 1926)

(Plate 5, Figures 1-2; Plate 7, Figures 5, 6)

Typical forms, mainly in the middle and upper Albian. Upper Aptian to upper Albian, sporadically to Coniacian.

Hedbergella planispira (Tappan, 1940)

(Plate 1, Figures 1, 2; Plate 7, Figures 7, 8)

The species is common in the two sites from upper Aptian to the end of Albian. Some isolated specimens are also recorded from the Coniacian.

\section{Hedbergella infracretacea (Glaessner, 1937)}

$$
\text { (Plate 1, Figures 5, 6) }
$$

The species is very abundant in both sites from upper Aptian to upper Albian.

\section{Hedbergella infracretacea gargasiana Moullade, 1961}

(Plate 1, Figures 7-9)

This is a small-sized species, with usually 4 chambers in the last whorl. It differs from Hedbergella excelsa Longoria which has 6 chambers and a lower Aptian range. It has been described by Moullade from the upper Gargasian of the "Fosse vocontienne," France. Upper Aptian, Globigerinelloides algeriana Zone, Sites 363 and 364

\section{Hedbergella gorbachikae Longoria, 1974}

(Plate 3, Figures 9-12)

The species occurs mainly in the Globigerinelloides algeriana Zone of Site 364, but some specimens continue into the Hedbergella gorbachikae Zone. It is practically absent at Site 363 .
Hedbergella labocaensis Longoria, 1974

(Plate 2, Figures 3, 4)

In the samples studied, this species could not be distinguished from Hedbergella similis, erected simultaneously by Longoria. Upper Aptian, Hedbergella gorbachikae Zone, Site 364.

\section{Hedbergella maslakovae Longoria, 1974}

(Plate 2, Figures 1, 2)

The species differs from Hedbergella bizonae Chevallier by having, in the last whorl, 7 chambers less radially elongated, and by its younger stratigraphic range. Upper Aptian, Hedbergella gorbachikae Zone, Site 364 .

\section{Hedbergella cf. trochoidea (Gandolfi, 1942)}

(Plate 6, Figures 5, 6)

In the sites studied, the species has never shown all the characters of the holotype. The number of chambers is always short by one or two: the trochospiral coil is low and, at times, ornamentation becomes dominant. Middle and upper Albian. Few specimens occur in the Hedbergella primula Zone; more in the Biticinella breggiensis and Rotalipora ticinensis zones.

Hedbergella costellata Saint-Marc, 1973

(Plate 4, Figures 1-3; Plate 4, Figures 8, 9)

Described from the middle Cenomanian of Lebanon, from a neritic, warm environment, numerous specimens, from Site 364 mainly, may be assigned to this species. However, investigation of Cores 363-29 and 364-30, and 364-31 shows a higher species diversity (according to Saint-Marc) and even genus diversity (Ticinella with "costulae," Praeglobotruncana with oriented rugosities).

A Hedbergella population, characterized by coarsely orientated rugosities, has also been recorded from the Southern Pyrénées in Coniacian marls (Fondecave, 1975). This author describes such forms under the new name of Hedbergella aubertae and provides illustrations which confirm an ornamentation relationship with Hedbergella costellata. The hypothesis of the environmental significance of test ornamentation relies on these three observations (Coniacian in the Pyrénées, Cenomanian of the Lebanon, Albian of the Angola Basin).

The appearance of the costulae is not limited by a definite stage of the Hedbergella evolution, but by the external factor due of a neritic environment. Middle to upper Albian, from Biticinella breggiensis Zone to Rotalipora ticinensis Zone. In the sites studied, the Hedhergella costellata episode would be older than those of Lebanon and the Pyrénées.

\section{Hedbergella portsdownensis (Williams-Mitchell, 1948)}

$$
\text { (Plate 10, Figures 1, 2) }
$$

The species occurs only in Core 23 of Site 364, Turonian, and reworked in the Tertiary Sample 3, CC of Site 365.

\section{Hedbergella crassa (Bolli, 1959) \\ (Plate 11, Figures 5, 6)}

A form with rounded periphery, low trochospiral, and which occurs from upper Turonian to Maestrichtian. It appears remarkably resistant to dissolution, perhaps because of the minute size of pores and lack of any ornamentation. Hedbergella holmdelensis Olsson is a probable synonym.

Hedbergella angolae Caron, n. sp.

(Holotype: Plate 10, Figures 5, 6, C 33.817

Paratype: Plate 10, Figure 7, C 33.818

Text-figures: 6a-c, C 33.825)

Holotype and paratypes are deposited at the Museum of Natural History, Basel, C 33.817, 33.818, 33.825-33.828).

Diagnosis: Test low trochospiral, nearly flat on spiral side, covered with coarse oriented pustulae, especially on first chambers of the last whorl. The ultimate chamber is smooth. Chambers globular, 5 to 5 $1 / 2$ in final whorl, increasing gradually in size, the last chamber increasing very rapidly, giving the test its specific appearance. Umbilicus wide. Primary aperture interiomarginal, umbilical to extraumbilical, bordered by an apertural flap. Greatest diameter of holotype $400 \mu \mathrm{m}$, of topotypes $350 \mu \mathrm{m}$. 


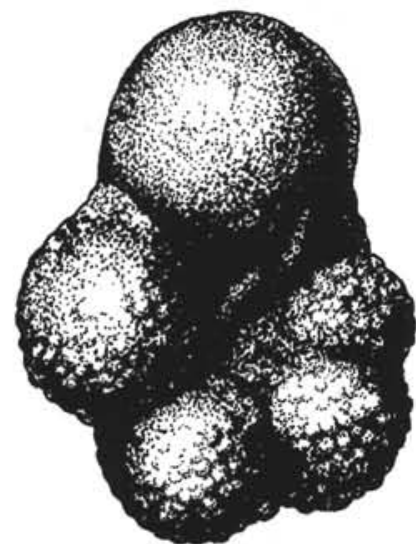

a

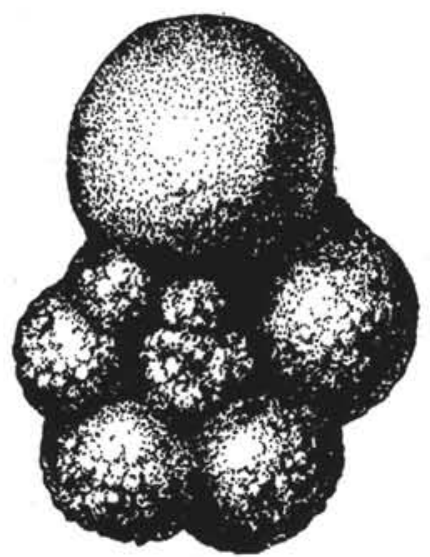

b

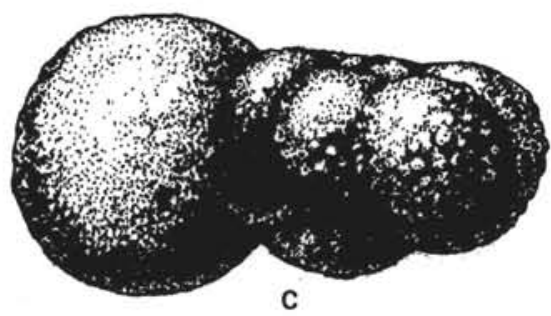

0
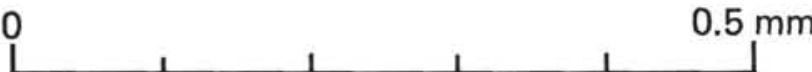

Figure 6. Hedbergella angolae Caron, n. sp., paratype, Sample 364-26, CC.

Remarks: The species shows coarse pustulae oriented along lines parallel with the periphery of each chamber. This characteristic ornamentation is also found on other ornamented species that occur in the same level: Hedbergella costellata. Whiteinella baltica, and $W$. bornholmensis.

Differences: The species differs from Globigerina caspia Vassilenko, 1961, by showing a lower trochospiral coil and more rapidly increasing chambers, and from Hedbergella aptiana Bartenstein, 1965, in being more evolute (J. Sigal, personal communication).

Holotype and paratypes: DSDP Leg 40, Angola Basin, Site 364 . Core 26 , core catcher.

Occurrence: Middle to upper Albian, through Ticinella primulaBiticinella breggiensis-Rotalipora ticinensis zones, Site 364 only.

Genus CLAVIHEDBERGELLA Banner and Blow, 1959

Clavihedbergella simplex (Loeblich and Tappan, 1961) (Plate 11, Figures 3, 4; Plate 8, Figures 1-4)
Clavihedbergella simplicissima (Magne and Sigal, 1954)

( = Hedbergella amabilis Loeblich and Tappan, 1961)

(Plate 8, Figures 5, 6)

Clavihedbergella subcretacea (Tappan, 1943)

(Plate 11, Figures 1, 2)

These species usually occur throughout the Cenomanian. Hedbergella? cf. simplicissima has been reported from the upper Albian of the Indian Ocean by Herb (1974) and Hedbergella amabilis by Luterbacher (1972) from the Western North Atlantic. The Clavihedbergella of the Angola Basin, and there also the Schackoina. are older than any other occurrences reported so far. Albian at Site 363: Albian, upper Coniacian at Site 364.

Genus HASTIGERINELLA Cushman, 1927

Hastigerinella cf. alexanderi Cushman, 1931

(Plate 11, Figure 7)

The majority of specimens recovered from Sample 364-22, CC, possesses more elongate chambers than the form illustrated on Plate 11, Figure 7. This latter specimen, which is of large size, is already transitional to Schackoina moliniensis.

Genus WHITEINELLA Pessagno, 1967

Whiteinella archaeocretacea Pessagno, 1967

Whiteinella baltica Douglas, 1969

(Plate 4, Figures 4, 5)

Whiteinella bornholmensis (Douglas, 1969)

(Plate 4, Figures 6, 7; Plate 10, Figures 3, 4)

The specimens of these three species recovered in the South Atlantic are rather similar to the respective holotypes, with the simple difference that the general trend of the primary aperture extends from an umbilical to an umbilical-extraumbilical position. They occur mainly in the upper Coniacian (Globotruncana primitiva Zone) of Site 364 , Angola Basin which agrees with data published by Douglas and Rankin (1969) and Pessagno (1967). However, they also occur in middle to upper Albian cores of Site 364 where they are associated with Hedbergella costellata, pointing to a dependence on environmental conditions rather than to an evolution within Whiteinella.

\section{Genus ARCHAEOGLOBIGERINA Pessagno, 1967}

\section{Archaeoglobigerina bosquensis Pessagno, 1967}

$$
\text { (Plate 10, Figures 8, 9) }
$$

The specimen illustrated here is not typical (juvenile form ?). It possesses $4-1 / 2$ chambers in the last whorl instead of 5 or 6 ; the primary aperture is umbilical, but extends towards the periphery. Middle-upper Albian, Site 364.

\section{Genus TICINELLA Reichel, 1950}

Ticinella bejaouensis Sigal, 1966

(Plate 2, Figure 9, 10)

Specimens of this species have been well preserved by casts in Site 364 . Core 34 . The external ornamentation has been removed but 8 chambers of the final whorl remain visible, showing gradual increase in size; the wall pores stand out as minute pustulae. The primary aperture is large and high, extend from the umbilicus to the periphery, and continues partly on the spiral side. Two small umbilical supplementary apertures occur on the last two chambers. Lower Albian, Ticinella bejaouensis Zone, Site 364.

Ticinella primula Luterbacher, 1963

(Plate 3, Figures 1-3; Plate 9, Figures 3, 4)

Few supplementary apertures occur in the observed specimens. Throughout the Albian at Sites 363 and 364. 
Ticinella roberti (Gandolfi), 1942

(cf. roberti, Plate 6, Figures 1-4)

This species is not typical in the South Atlantic. The number of chambers is always less than the holotype (6 to $6-1 / 2$ in the last whorl) and the trochospire is low; a tendency towards the genus Biticinella appears in some specimens (Plate 6, Figures 1,2). Middle to upper Albian, Biticinella breggiensis Zone to Rotalipora ticinensis Zone, Sites 363 and 364.

\section{Ticinella raynaudi Sigal, 1966}

(Plate 9, Figures 8, 9)

\section{Ticinella raynaudi aperta Sigal, 1966}

(Plate 9, Figures 3, 4)

Specimens are fairly numerous; supplementary apertures are only rarely well developed ( 1 or 2 in the last whorl). Lower to upper Albian, Site 364.

\section{Ticinella madecassiana Sigal, 1966}

(Plate 3, Figures 4, 5)

Occurs throughout the Albian in Site 364.

Ticinella praeticinensis Sigal, 1966

(Plate 7, Figures 1,2)

Specimens have 1 or 2 chambers less than the holotype. The primary aperture is clearly visible, umbilical to extraumbilical in position. Umbilical sutural supplementary apertures are infrequent and not easily visible. Earlier chambers of the last whorl are covered by coarse ornamentation. Middle to upper Albian, Biticinella breggiensis-Rotalipora ticinensis zones, Sites 363 and 364.

Biticinella cf. breggiensis (Gandolfi, 1942)

(Plate 3, Figures 5-7)

Some specimens that contain only 6 chambers in the last whorl. Middle Albian Site 364, Core 31, Section 1.

\section{Genus ROTALIPORA Brotzen, 1942}

Rotalipora appenninica (Renz, 1936), Sample 365-3, CC. Rotalipora cushmani (Morrow, 1934), Sample 364-23-3, 58-60 cm.

Only one specimen of each species has been recorded. In the case of Rotalipora appenninica the specimen occurs reworked in the OligoMiocene.

\section{Genus PRAEGLOBOTRUNCANA Bermudez, 1952}

Praeglobotruncana delrioensis (Plummer, 1931)

Pustulae concentrate and are oriented along a peripheral band as large as but not identical to a true keel. The ultimate chamber has a globular aspect similar to Hedbergella delrioensis, its phylogenetic ancestor and with which it overlaps. Middle to upper Albian, Ticinella primula-Biticinella breggiensis-Rotalipora ticinensis zones, Sites 363 and 364 .

Other Upper Cretaceous genera Marginotruncana Hofker, 1956 Globotruncana (Cushman, 1927), Rugoglobigerina Bronnimann, 1952, etc. are not described in this paper. They are essentially tethyan species, frequently illustrated in the literature.

\section{ACKNOWLEDGMENTS}

I am greatly indebted to Dr. H.M. Bolli, who critically read the manuscript and made a number of valuable suggestions; to Dr. J. Sigal, who helped me with the problem of the validity and taxonomical position of Hedbergella angolae $\mathrm{n}$. sp. Dr. P. Homewood kindly checked the English manuscript. For technical assistance in typing and drafting, I wish to thank Mrs. F. Chammartin and Mr. G. Papaux. The micrographs were taken with I.S.I. Super Mini SEM at the Geological Institute of the University of Fribourg.

\section{REFERENCES}

Bolli, H.M., 1959. Planktonic foraminifers from the Cretaceous of Trinidad, B.W.I.: Am. Paleontol. Bull., v. 39 , p. $257-277$.

Caron, M., 1961. Globotruncanidae du Crétacé supérieur du synclinal de la Gruyère (Préalpes médianes, Suisse): Rev. Micropal., v. 9, p. 68-93.

1970. Quelques cas d'instabilité des caractères génériques chez les Foraminiferes planctoniques de l'Albien: Proc. Second Plankt. Conf., Rome, p. 145-157.

Caron, M. and Luterbacher, H.P., 1969. On some type specimens of Cretaceous planktonic foraminifera: Contrib. Cushman Found. Foram. Res., v. 20, p. 23-29.

Douglas, R.G. and Rankin, C., 1969. Cretaceous Planktonic Foraminifera from Bornholm and their zoogeographic significance: Lethaia, v. 2, p. 185-217.

Fondecave, M.J., 1975. Essai de biozonation par les Foraminiferes pélagiques du Sénonien sud-pyrénéen. Description d'une nouvelle espèce "Hedbergella aubertae n. sp.": Géologie Méditerranéenne, v. 2, p. 5-10.

Herb, R., 1974. Cretaceous Planktonic Foraminifera from the Eastern Indian Ocean: In Davies, T. A., Luyendyk, B.P., et al., Initial Reports of the Deep Sea Drilling Project, Volume 26: Washington (U.S. Government Printing Office), p. 745-769.

Loeblich, A. and Tappan, H., 1961. Cretaceous planktonic foraminifera: Part I-Cenomanian: Micropaleontology, v. 7 , p. $257-304$.

Longoria, J.F., 1974. Stratigraphic, morphologic, and taxonomic studies of Aptian planktonic foraminifera: Num. Esp. Rev. Española Micropal., diciembre 1974.

Longoria, J.F. and Gamper, M.A., 1975. The classification and evolution of Cretaceous planktonic foraminifera. Part 1: The Superfamily Hedbergelloidea: Num. Esp. Rev. Española Micropal., enero 1975.

Luterbacher, H., 1972. Foraminifera from the Lower Cretaceous and Upper Jurassic of the Northwestern Atlantic. In Hollister, C.D., Ewing, J.I., et al., Initial Reports of the Deep Sea Drilling Project, Volume 11: Washington (U.S. Government Printing Office), p. 561593.

1975. 25. Early Cretaceous Foraminifera from the Northwestern Pacific. In Larson, R.L., Moberly, R., et al., Initial Reports of the Deep Sea Drilling Project, Volume 32: Washington (U.S. Government Printing Office), p. 703-718.

Michael, F.Y., 1972. Planktonic foraminifera from the Comanchean series (Cretaceous) of Texas: J. Foram. Res., v. 2 , p. $200-220$.

Moullade, M., 1966. Etude stratigraphique et micropaléontologique du Crétacé inférieur de la "Fosse Vocontienne": Documents Labo. Géol. Fac. Sci. Lyon, fasc. 1, 2, p. 1-369.

Pessagno, E.A., Jr., 1967. Upper Cretaceous planktonic foraminifera from the Western Gulf coastal Plain: Palaeontographica Americana, v. 5, p. 249-445.

Pessagno, E.A., Jr., and Longoria, J.F., 1973. Mesozoic Foraminifera. In Edgar, N.T., Saunders, J. B., et al., Initial Reports of the Deep Sea Drilling Project, Volume 15: Washington (U.S. Government Printing Office), p. 549552.

Porthault, B., 1974. Le Crétacé supérieur de la "Fosse Vocontienne" et des régions limitrophes (France Sud-Est): Thèse Université Claude-Bernard, Lyon.

Reichel, M., 1947. Les Hantkéninidés de la Scaglia et des Couches rouges (Crétacé supérieur): Eclog. Geol. Helv., v. 40 , p. $391-409$. 
Renz, O., Luterbacher, H., and Schneider, A., 1963. Stratigraphisch-paläontologische Untersuchungen im Albien und Cenomanien des Neuenburger-Jura: Eclog. Geol. Helv., v. 56, p. 1073-1116.

Saint-Marc, P., 1973. Présence de Hedbergella à "costellae" dans le Cénomanien moyen du Liban: J. Foram. Res., v. 3 , p. $7-12$.

Sigal, J., 1966. Contribution à une monographie des Rosalines. 1. Le genre Ticinella Reichel, souche des Rotalipores: Eclog. Geol. Helv., v. 59, p. 185-217.
1974. Comments on Leg 25 sites in relation to the Cretaceous and Paleogene stratigraphy in the Eastern and Southeastern Africa Coast and Madagascar regional setting. In Simpson, E.S.W., Schlich, R., et al., Initial Reports of the Deep Sea Drilling Project, Volume 25: Washington (U.S. Government Printing Office), p. 687723.

Van Hinte, J.E., 1976. A Cretaceous time scale: Am. Assoc. Petrol. Geol. Bull., v. 60, p. 498-516. 
PLATE 1

Upper Aptian

Figures 1, 2 Hedbergella planispira (Tappan).

Sample 363-36-1, 74-76 cm.

C $33.768 . \times 300$.

Figures 3, 4 Globigerinelloides? maridalensis (Bolli).

Sample 363-37-1, 50-52 cm.

C 33.769 . $\times 300$.

Figures 5, 6 Hedbergella infracretacea (Glaessner).

Sample 363-37-1, 50-52 cm.

C $33.770 . \times 300$.

Figure 7 Hedbergella infracretacea gargasiana Moullade.

Sample 364-41-2, 131-132 cm.

C 33.771. $\times 150$.

Figures 8, 9 Hedbergella infracretacea gargasiana Moullade.

Sample 364-41-2, 131-132 cm.

C $33.772 . \times 150$.

Figure $10 \quad$ Hedbergella cf. washitensis (Carsey).

Sample 363-38, CC.

C 33.773. $\times 300$.

PLATE 2

Figures 1-4: Upper Aptian; Figures 5-10: Lower Albian; All figures $\times 150$.

Figures 1, 2 Hedbergella maslakovae Longoria.

Sample 364-35-3, 65-66 cm.

C 33.774 .

Figures 3,4 Hedbergella labocaensis (= similis) Longoria. Sample 364-35-3, 65-66 cm.

C 33.775 .

Figures 5, $6 \quad$ Globigerinelloides bentonensis (Morrow).

Sample 364-34-3, 11-12 cm.

C 33.776.

Figures 7, 8 Globigerinelloides texomaensis Michael.

Sample 364-34-3, 11-12 cm.

C 33.777.

Figures 9-10 Ticinella bejaouensis Sigal.

Sample 364-34-3, 11-12 cm.

C 33.778 .

(see p. 664) 

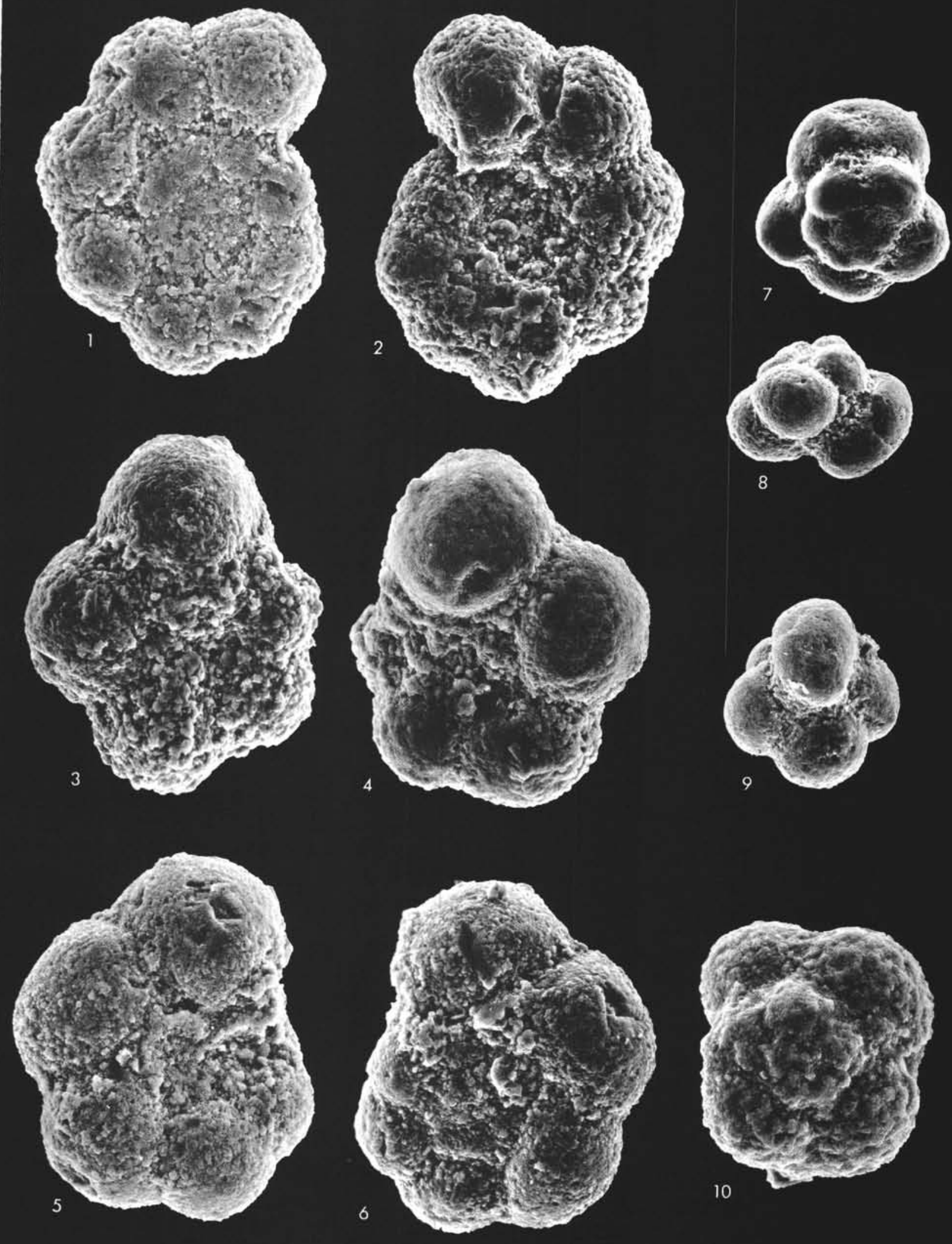

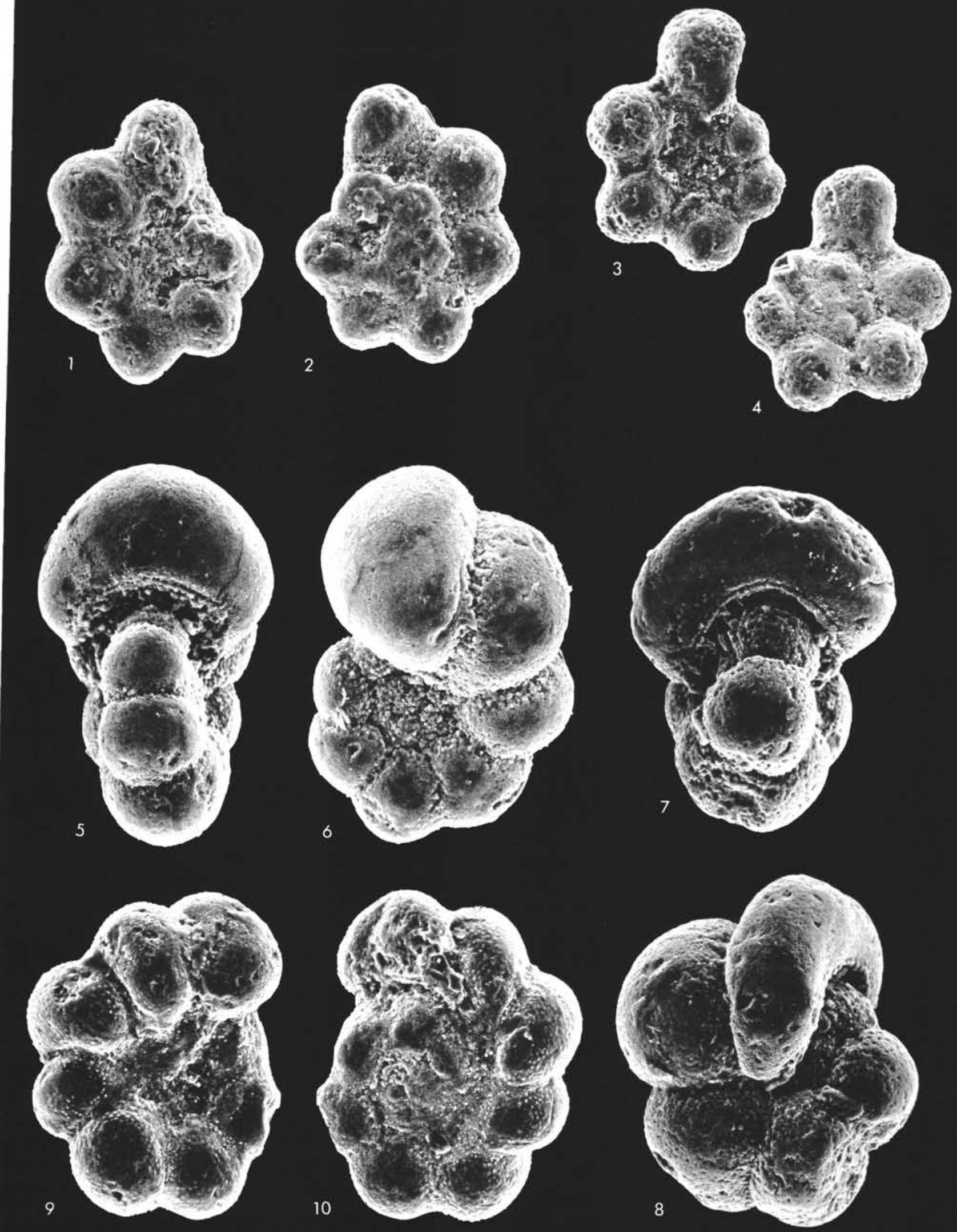


\section{PLATE 3}

Middle Albian: All figures $\times 150$ except Figure $3, \times 300$.

Figures 1,2 Ticinella primula Luterbacher. Sample 364-31, CC.

C 33.779 .

Figure 3 Umbilical detail of Figure 2, only one supplementary aperture.

Figures 4, 5 Ticinella madecassiana Sigal.

Sample 364-31, CC.

C 33.780 .

Figure $6 \quad$ Biticinella $\mathrm{cf}$. breggiensis (Gandolfi).

Sample 364-31, CC.

C 33.781 .

Figure $7 \quad$ Biticinella cf. breggiensis (Gandolfi).

Sample 364-31, CC.

$$
\text { C } 33.782 \text {. }
$$

Figure 8 Globigerinoides caseyi (Bolli, Loeblich, and Tappan).

Sample 364-31, CC.

C 33.783 .

Figures 9, 10 Hedbergella gorbachikae Longoria.

Sample 364-31, CC.

C 33.784 .

Figures 11, 12 Hedbergella gorbachikae Longoria.

Sample 364-31, CC.

C 33.785 .

(see p. 666)

\section{PLATE 4}

Angola Basin; middle and upper Albian.

Figures 1,2 Hedbergella costellata Saint Marc.

Sample 364-27-2, top.

C $33.786 . \times 150$.

Figure 3 Detail of pustulae of Figure 1.

Figures 4, 5 Whiteinella baltica Douglas.

Sample 364-31-1, $57-59 \mathrm{~cm}$.

C 33.787. $\times 300$.

Figures 6,7 Whiteinella bornholmensis (Douglas).

Sample 364-31-1, 57-59 cm.

C $33.788 . \times 150$.

Figure $8 \quad$ Hedbergella cf. costellata Saint Marc.

Sample 364-30, CC.

C 33.789. $\times 90$.

Figure 9 Detail of costellae, Figure 8. $\times 300$.

(see p. 667) 
PLATE 3

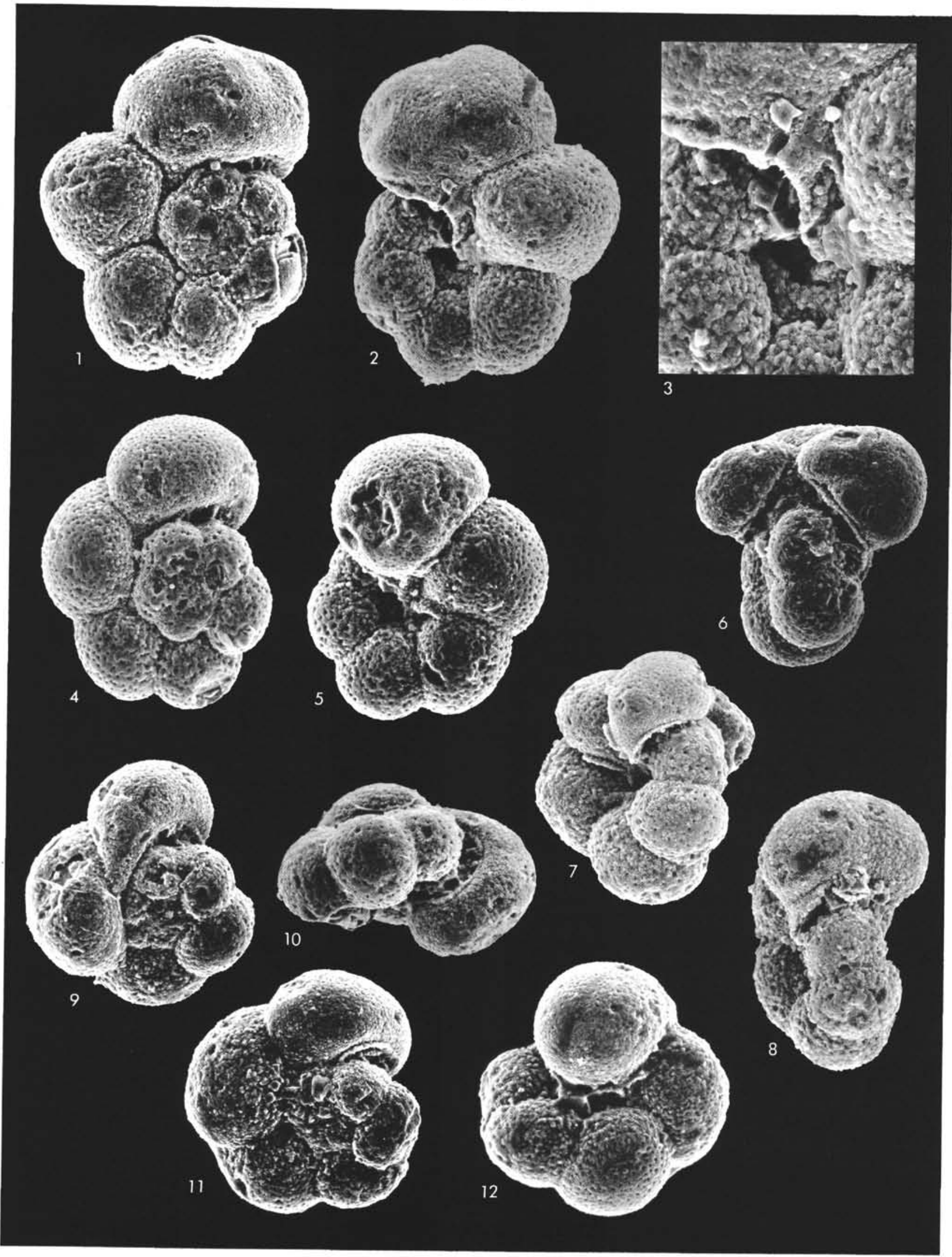




\section{PLATE 4}
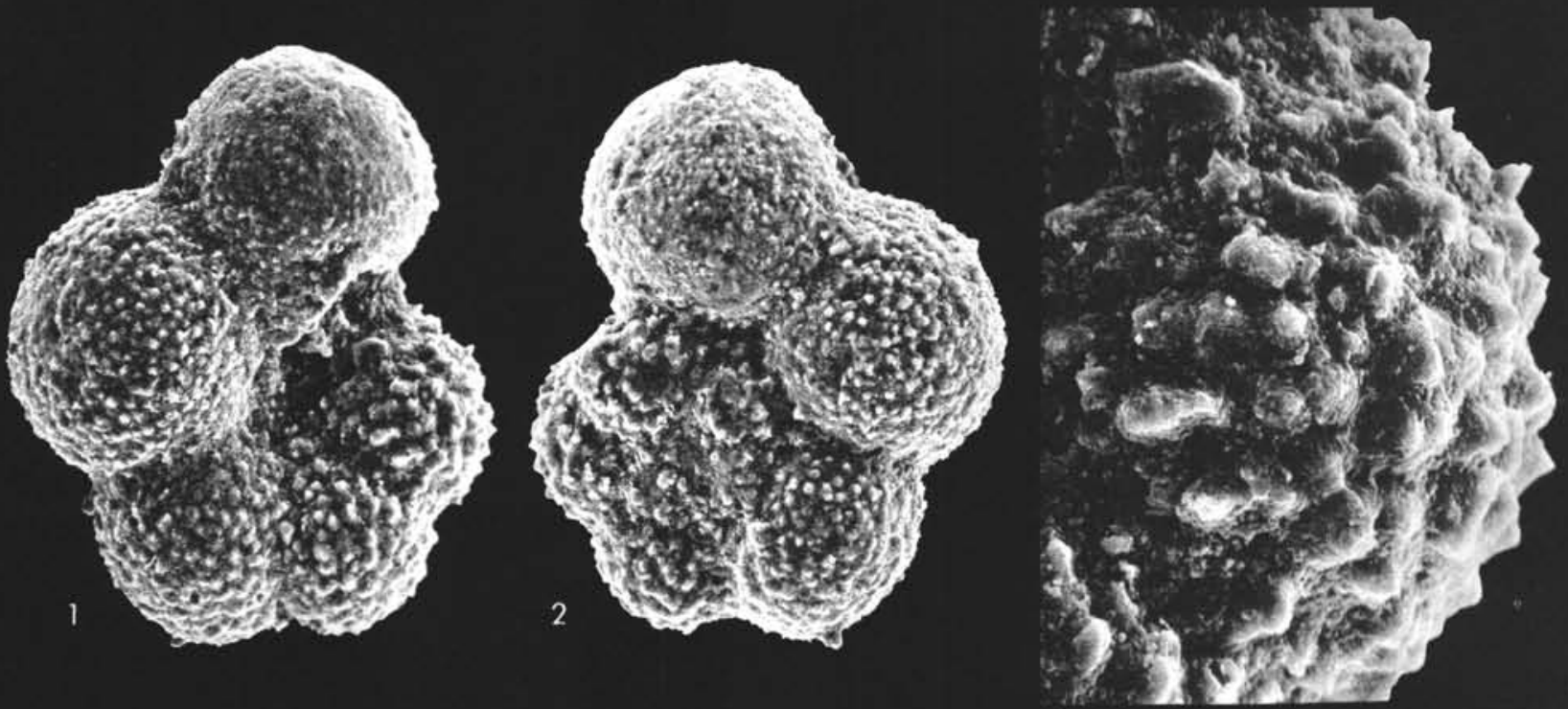

3
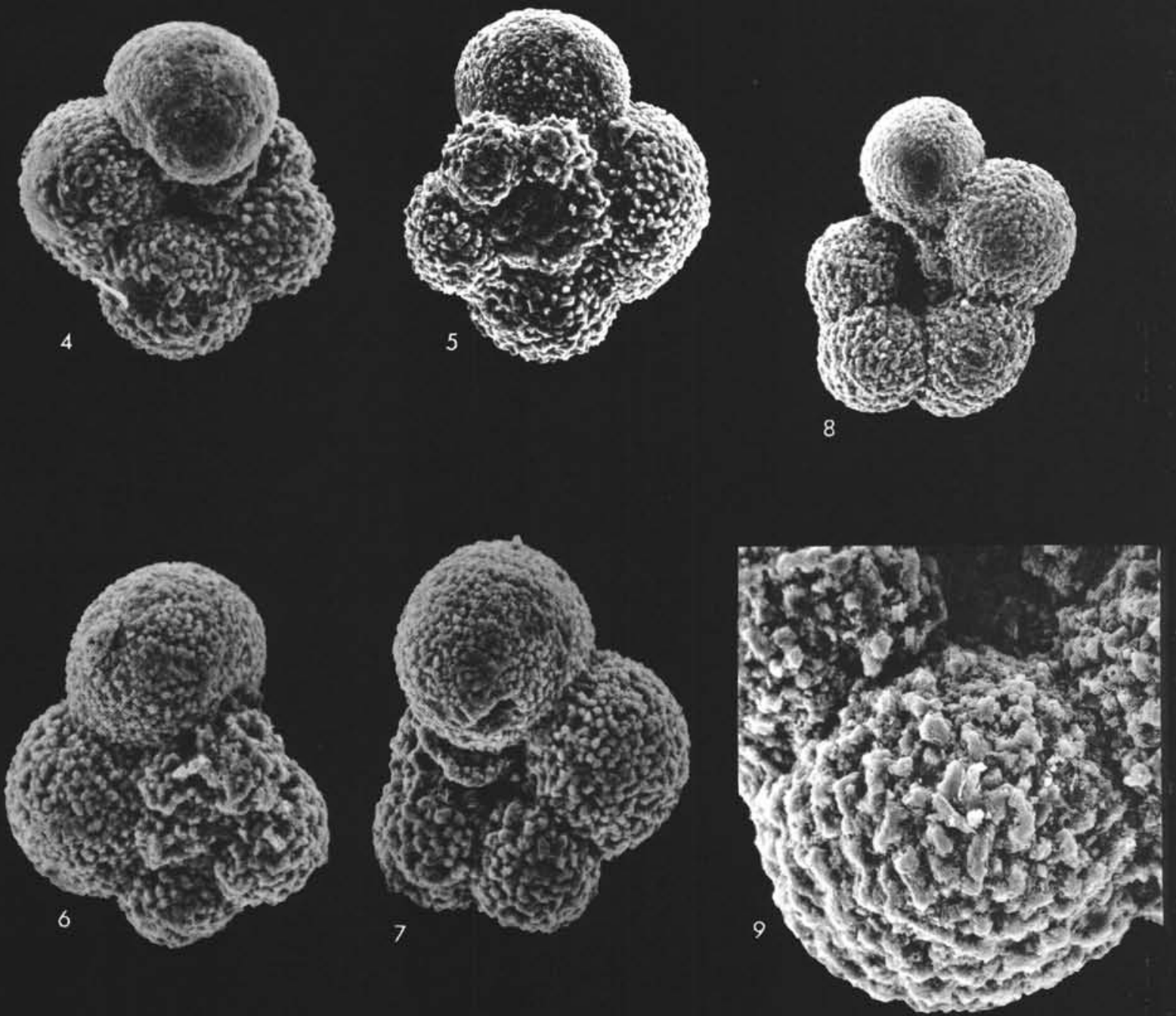
PLATE 5

Angola Basin; middle and upper Albian.

Figures 1, 2 Hedbergella delrioensis (Carsey).

Sample 364-28, CC.

C $33.790 . \times 150$.

Figures 3, $4 \quad$ Hedbergella $\mathrm{cf}$. infracretacea (Glaessner).

Sample 364-27-2, top.

C $33.791 . \times 150$.

Figures 5,6 Ticinella ? sp. ?.

Sample 364-31, CC.

C $33.792 . \times 150$.

Figure 7 Detail of Figure 8. $\times 300$.

Figure $8 \quad$ Ticinella sp. ? with "costellae" and supplementary apertures.

Sample $364-31-1,57-59 \mathrm{~cm}$

C $33.793 . \times 90$.

\section{PLATE 6}

Angola Basin; middle and upper Albian.

Figures 1,2 Ticinella cf. roberti $\rightarrow$ Biticinella.

Sample 364-30, CC.

C $33.794 . \times 90$.

Figures 3, $4 \quad$ Ticinella cf. roberti (Gandolfi).

(6 chambers).

Sample 364-30, CC.

C $33.795 . \times 90$.

Figures 5,6 Hedbergella cf. trochoidea (Gandolfi).

(5-1/2 chambers).

Sample 364-31-1, $57-59 \mathrm{~cm}$.

C 33.796. $\times 90$.

Figure $7 \quad$ Umbilical detail without supplementary apertures.

$\times 300$.

Figure $8 \quad$ Globigerinelloides caseyi (Bolli, Loeblich, and Tappan).

Sample 364-29, CC.

C $33.797 . \times 150$.

Figures 9, 10 Idem.

Sample 364-28-1, 49-50 cm.

C $33.798 . \times 150$.

Figures 11, 12 Globigerinelloides blowi (Bolli).

Sample 364-28-1, 49-50 cm.

C $33.799 . \times 150$.

(see p. 670) 


\section{PLATE 5}
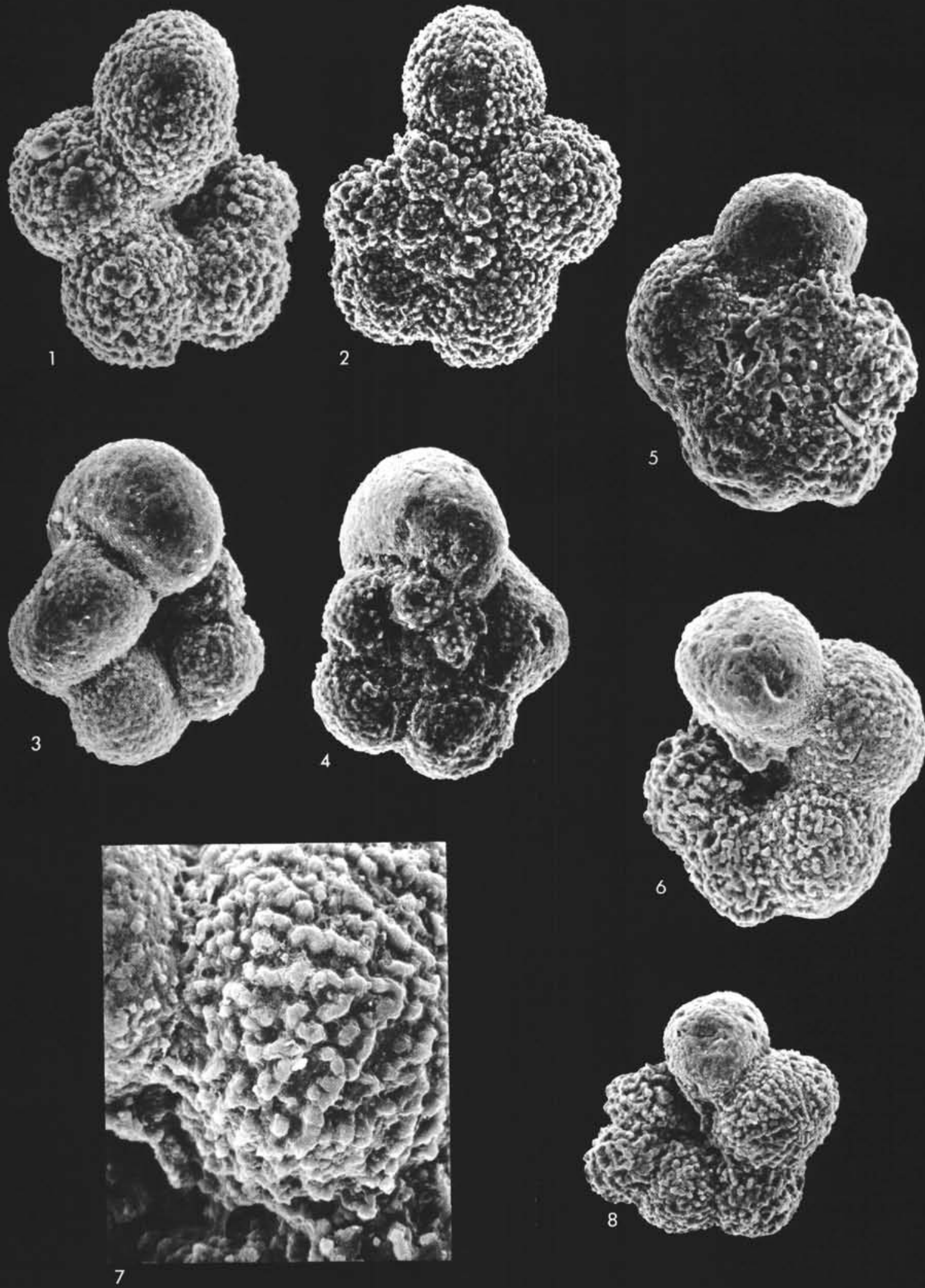
PLATE 6

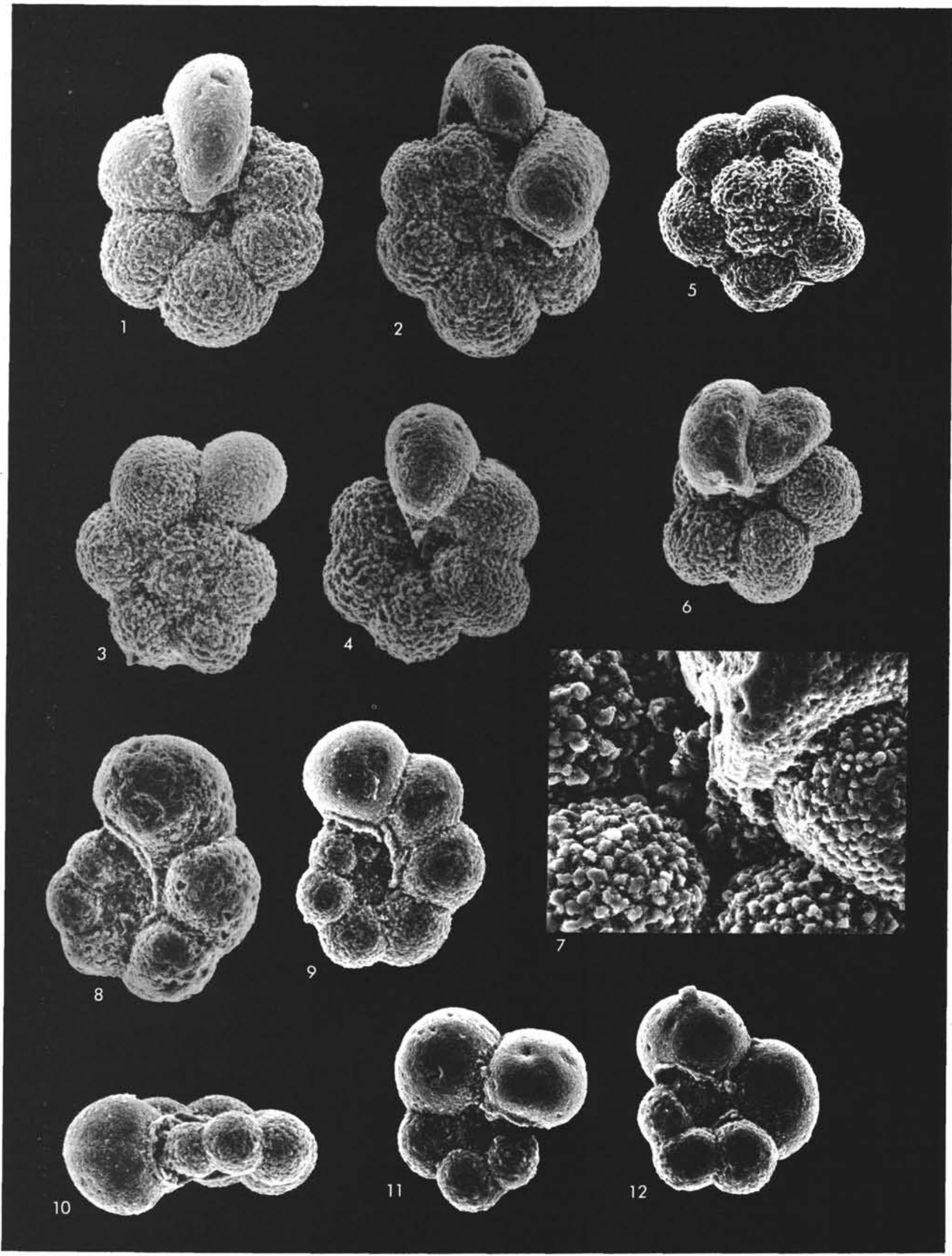




\section{PLATE 7}

Angola Basin; middle and upper Albian; all figures $\times 150$.
Figures 1,2 Ticinella praeticinensis Sigal.
Sample 364-28-1, 49-50 cm.
C 33.800 .

Figures 3, $4 \quad$ Praeglobotruncana delrioensis (Carsey).

Sample 364-28-1, 49-50 cm.

C 33.801 .

Figures 5,6 Hedbergella delrioensis (Carsey).

Sample 364-28-1, 49-50 cm.

C 33.802 .

Figures 7,8 Hedbergella planispira (Tappan).

Sample 364-27-2, top.

C 33.803 .

(see p. 672)

\section{PLATE 8}

Angola Basin; upper Albian; all figures $\times 150$.

Figures 1,2 Clavihedbergella simplex (Loeblich and Tappan). Sample 364-27-2, top.

$$
\text { C } 33.804 \text {. }
$$

Figures 3,4 Idem.

Sample 364-27-2, top.

C 33.805 .

Figures 5,6 Clavihedbergella simplicissima (Magne and Sigal). Sample 364-27-2, top.

$$
\text { C } 33.806 \text {. }
$$

Figure 7

Schackoina pentagonalis aperta Reichel.

Sample 364-26, CC.

C 33.807 .

Figure 8

Schackoina cenomana (Schacko).

Sample 364-26, CC.

C 33.808 .

Figure 9

Schackoina cenomana (Schacko)

Sample 364-28-1, 49-50 cm.

C 33.809 .

Figures 10,11 Schackoina moliniensis Reichel.

Sample 364-26, CC.

C 33.810 .

(see p. 673) 


\section{PLATE 7}

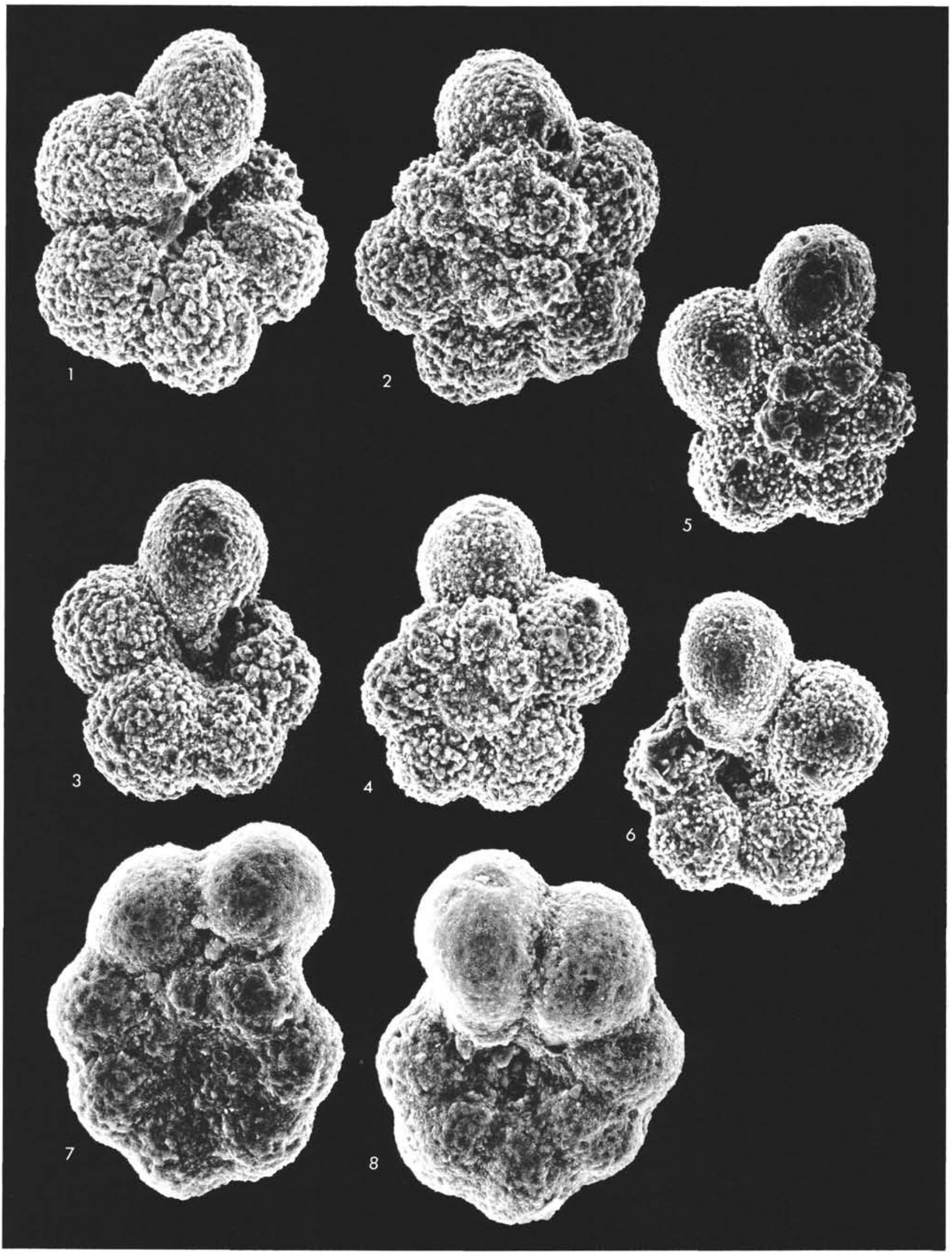




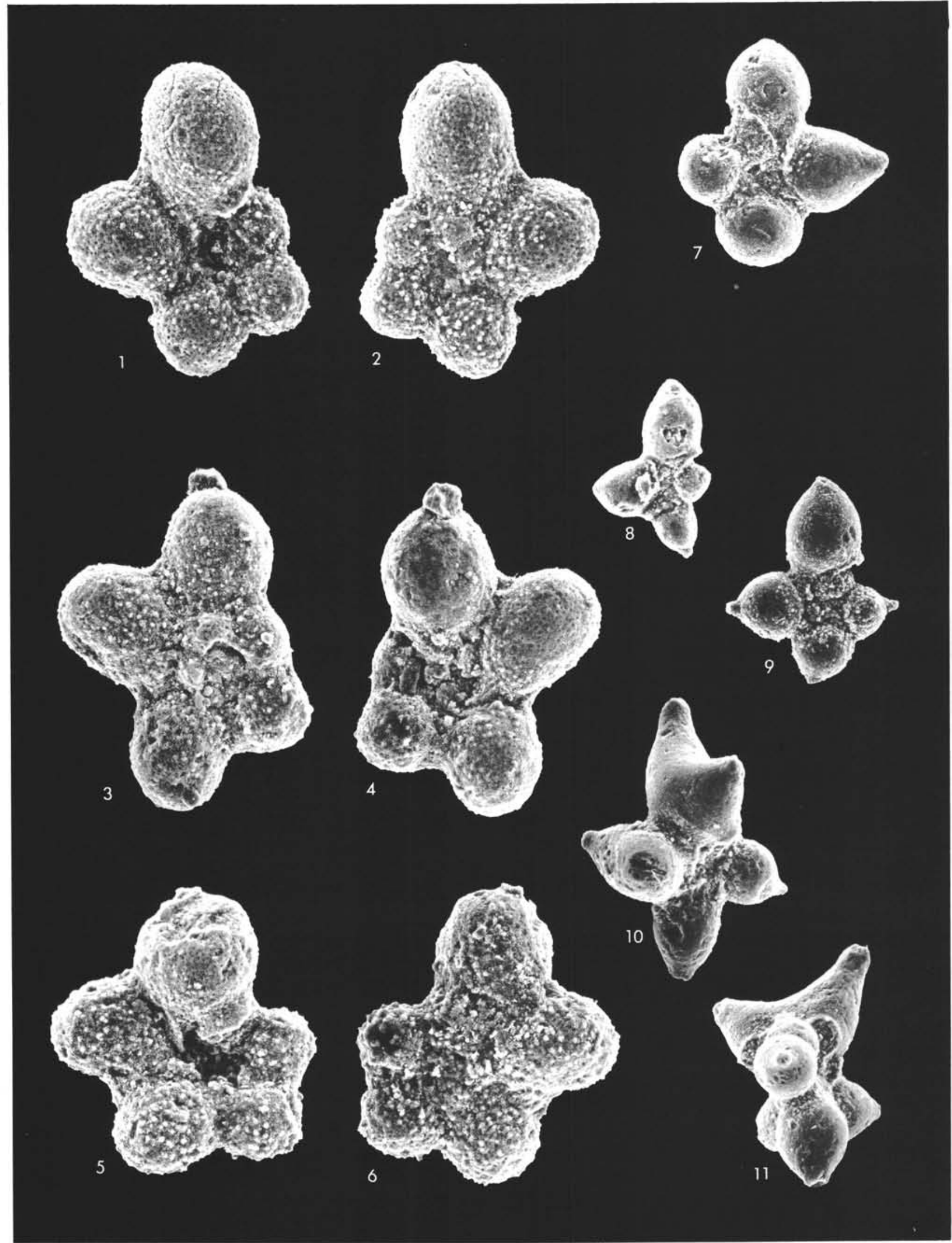




\section{PLATE 9}

Angola Basin; upper Albian; all figures $\times 150$ except Figure 5, $\times 300$.
Figures 1,2 Ticinella primula Luterbacher. Sample 364-26, CC. C 33.811 .

Figures 3,4 Ticinella raynaudi aperta Sigal. Sample 364-26, CC. C 33.812 .

Figure 5 Umbilical view, detail of Figure 3.

Figures 6,7 Hedbergella ? ou Ticinella sp. Sample 364-26, CC.

C 33.813 .

Figures 8, 9 Ticinella raynaudi Sigal. Sample 364-26, CC.

C 33.814 .

PLATE 10

Angola Basin; upper Albian; all figures $\times 150$ except Figures 5-7, $\times 90$.

Figures 1, 2 Hedbergella portsdownensis (Williams-Mitchell). Sample 364-23-3, 58-60 cm. C 33.815 .

Figures 3, 4 Whiteinella bornholmensis (Douglas). Sample 364-26, CC. C 33.816 .

Figures 5, 6 Hedbergella angolae Caron, n. sp. Sample 364-26, CC.

Holotype (C 33.817)

Figure 7

Hedbergella angolae Caron, n. sp. Sample 364-26, CC. Paratype (C 33.818$)$.

Figures 8,9 Archaeoglobigerina cf. bosquensis Pessagno (juvenile form ?).

Sample 364-27-2, top.

C 33.819 . 
PLATE 9

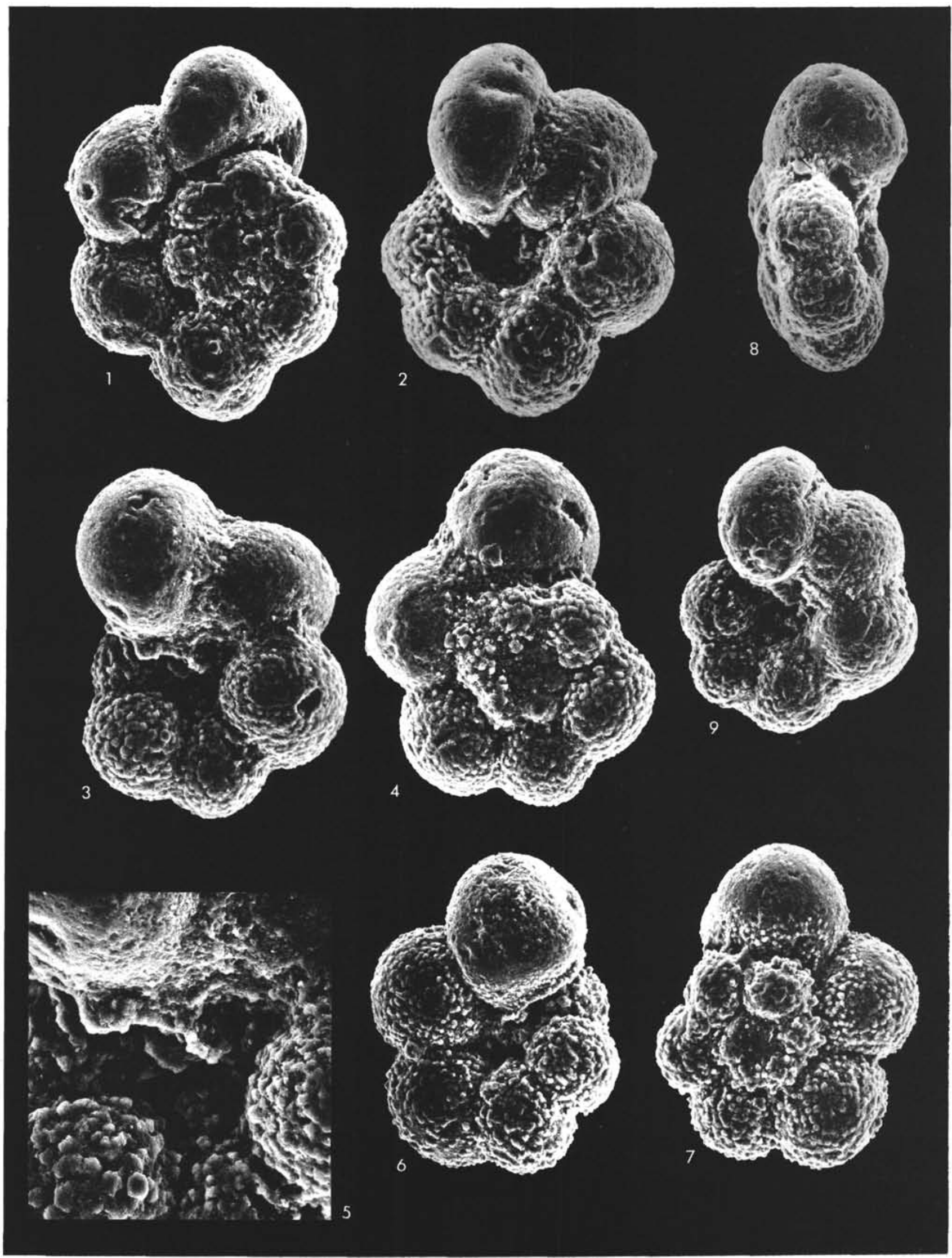




\section{PLATE 10}
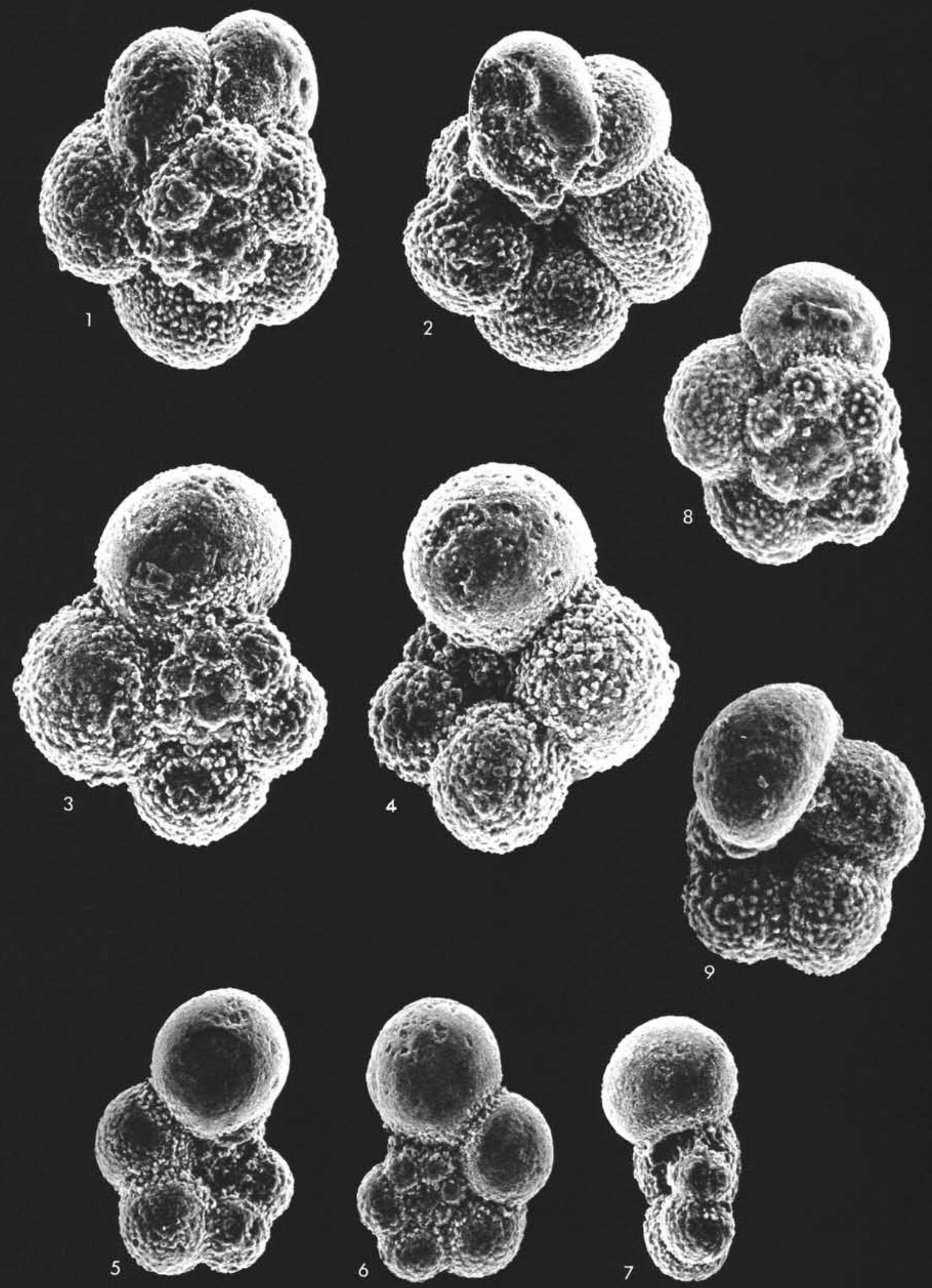
PLATE 11

Figures 1-7: Upper Coniacian; Figures 8, 9: upper Albian; all figures $\times 150$ except Figures 1 and 2, $\times 90$.

Figures 1,2 Clavihedbergella subcretacea (Tappan). Sample 364-22, CC.

C 33.820 .

Figures 3,4 Clavihedbergella simplex (Loeblich and Tappan). Sample 364-21, CC. C 33.821 .

Figures 5,6 Hedbergella crassa (Bolli). Sample 364-16, CC. C 33.822 .

Figure $7 \quad$ Hastigerina $\mathrm{cf}$. alexanderi Cushman. Sample 364-22, CC. C 33.823 .

Figures 8,9 Hedbergella cf. excelsa Longoria. Reworked form from lower Aptian. Sample 364-26-1, 99-101 cm. C 33.824 . 

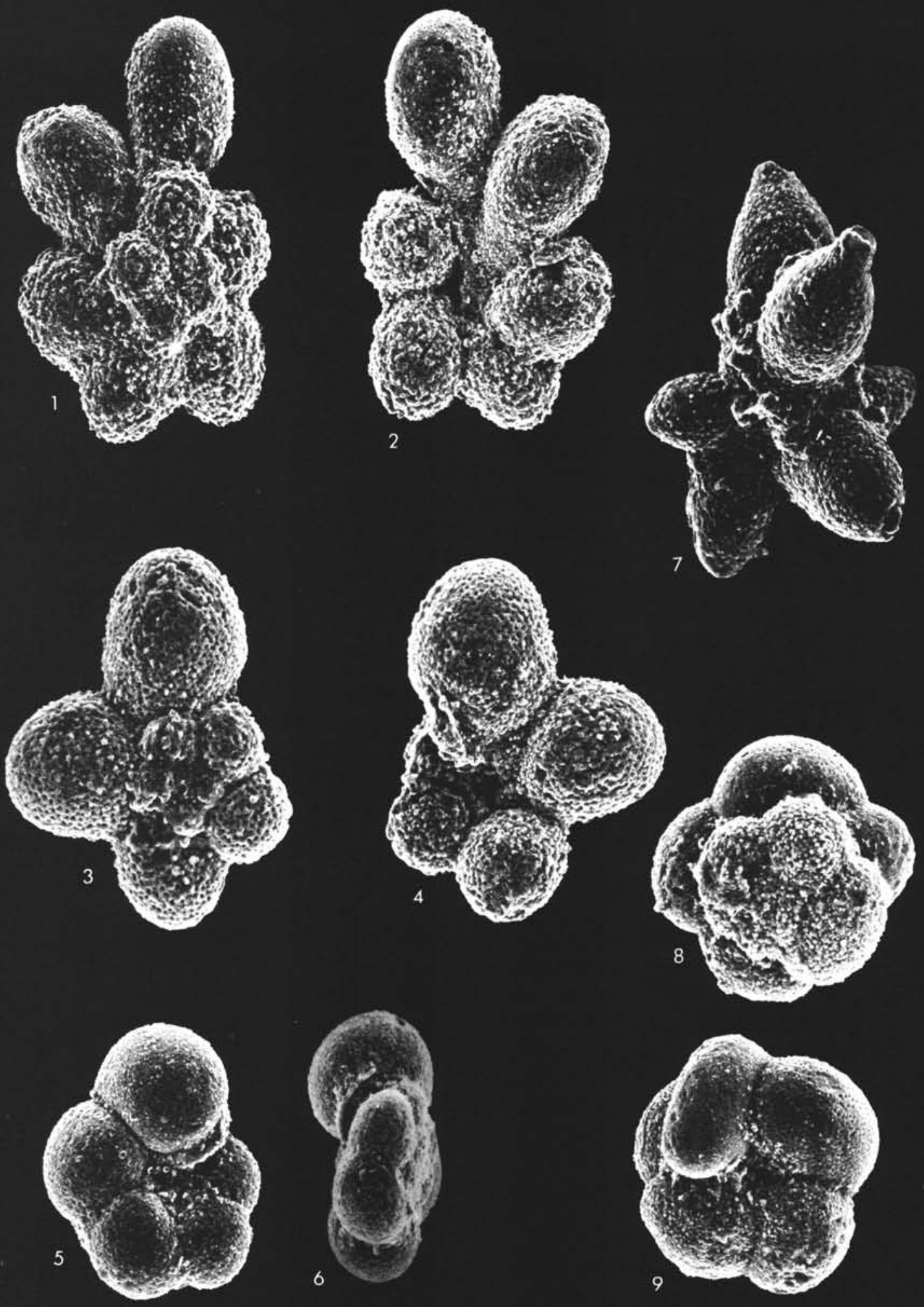